LAS RESTRICCIONES NO ARANCELARIAS

ARGENTINAS EN EL MERCOSUR:

NORMAS Y POLÍTICA EN LOS

CONFLICTOS COMERCIALES

\title{
Luciana GIL
}

Rosario, abril-junio 2015 - № 120 


\section{CUADERNOS DE POLITICA EXTERIOR ARGENTINA}

ISSN 0326-7806 (edición impresa)
ISSN 1852-7213 (edición en línea)

DIRECTOR: Dr. Alfredo Bruno BOLOGNA

Consejo Nacional de Investigaciones Científicas y Técnicas (CONICET)

CONSEJO DE REDACCION: Magister Anabella Busso (CONICET)

Dra. Miryam Colacrai (CONICET)

Dra. Gladys Lechini de Álvarez (CONICET)

Lic. Gustavo Marini (UNR)

Prof. Celestino del Arenal (España)

Prof. Eduardo Ferrero Costa (Perú)

Prof. Helio Jaguaribe (Brasil)

Prof. Carlos Juan Moneta (Argentina)

Prof. Juan Gabriel Tokatlian (Argentina)

Prof. Joseph S. Tulchin (Estados Unidos)

Prof. Alberto van Klaveren (Chile)

En memoria de los Consejeros: Prof. Jack Child

Prof. Juan Carlos Puig

Prof. Luciano Tomassini

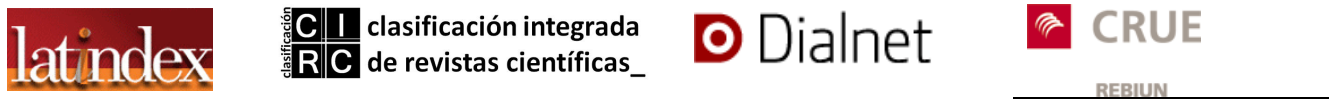

Dirección Nacional de Derecho de Autor: 5167887/14

Publicación trimestral propiedad de Alfredo Bruno Bologna (abologna@unr.edu.ar)

Indexada: Latindex Catálogo. Nivel I de excelencia

Clasificación Integrada de Revistas Científicas (CIRC): Grupo C

Catalogada: Dialnet (Universidad de La Rioja, España)

Red de Bibliotecas Universitarias (REBIUN) de la Conferencia de Rectores de Universidades Españolas (CRUE)

Los trabajos son sometidos a evaluación de expertos mediante el sistema doble ciego.

Las opiniones vertidas son de exclusiva responsabilidad de sus autores y no reflejan, necesariamente, la de los Cuadernos de Política Exterior Argentina.

Colaboración en traducciones: Laura Marsol

Edición: Mag. Lidia Gatti

Al final de este número se detalla el listado de las publicaciones del CERIR. El texto completo de los Cuadernos de Política Exterior Argentina señalados con el asterisco $\left({ }^{*}\right)$ está disponible en la página web http://www.cerir.com.ar

Correo electrónico: cerir@unr.edu.ar

CORRESPONDENCIA Y CANJE - ADDRESS OF CHANGE

CENTRO DE ESTUDIOS EN RELACIONES INTERNACIONALES DE ROSARIO CERIR

San Juan 4290

S2002OVV ROSARIO (SANTA FE)

REPUBLICA ARGENTINA

TEL/FAX.: 54-341-4201231 


\title{
EDITORIAL
}

El Centro de Estudios en Relaciones Internacionales de Rosario (CERIR) es una institución sin fines de lucro dedicada a la investigación y la docencia en el área de las Relaciones Internacionales.

EI CERIR inició sus actividades en 1985 en el ámbito docente de la Facultad de Ciencia Política y Relaciones Internacionales de la Universidad Nacional de Rosario. Desde entonces, concreta su labor en proyectos conjuntos presentados al CONICET, que se fueron enriqueciendo progresivamente con la incorporación de investigadores y becarios. Los trabajos elaborados se conocen a través de la publicación periódica Cuadernos de Política Exterior Argentina.

En este marco, el CERIR diseña en 1992 un Programa de Investigación cuyo objetivo es el seguimiento de la Política Exterior Argentina. Los resultados de este Programa se han plasmado en la publicación de las siguientes obras conjuntas: "La Política Exterior del Gobierno de Menem. Seguimiento y Reflexiones al promediar su mandato" (1994); "La Política Exterior Argentina 1994/1997" (1998); "La Política Exterior Argentina 1998-2001. El cambio de gobierno ¿Impacto o irrelevancia?" (2001); "La Política Exterior del gobierno de Kirchner" (2006); "La política exterior de Cristina Fernández. Apreciaciones promediando su mandato" (2010); el último tomo, "La política exterior de Cristina Fernández de Kirchner al finalizar su mandato" (2015), constituye un esfuerzo colectivo sostenido de los investigadores del CERIR, al que en esta oportunidad se han sumado alumnos de la Maestría en Integración y Cooperación Internacional.

La Maestría en Integración y Cooperación Internacional es organizada por nuestro Centro de Estudios en el ámbito del Centro de Estudios Interdisciplinarios (CEI) de la UNR. Esta carrera de posgrado constituye el ámbito por excelencia de transferencia de conocimientos por parte de los investigadores del CERIR. La Maestría tiene el orgullo de haber recibido desde sus comienzos, en 1996, a graduados del país y del extranjero, becarios del Sector Educativo del MERCOSUR, la Organización de Estados Iberoamericanos (OEI), la Organización de Estados Americanos (OEA), la Agencia Española de Cooperación Internacional (AECI), y de haber participado del programa ALFA-DEIMPIR (Desarrollo Económico e Institucional mediante Procesos de Integración Regional) de la Unión Europea.

Los Cuadernos de Política Exterior Argentina se encuentran abiertos a la participación de docentes e investigadores ajenos al CERIR que deseen presentar temas referidos a los proyectos de investigación en curso.

\author{
Dr. Alfredo Bruno Bologna \\ Director del CERIR
}




\title{
Las restricciones no arancelarias argentinas en el MERCOSUR: normas y política en los conflictos comerciales
}

Luciana GIL **

\section{Resumen}

Este artículo aborda las restricciones no arancelarias como problema constante en la agenda del MERCOSUR. Analiza la propia definición de "restricción" o "barrera" a nivel internacional, observando que dificulta su identificación y genera discusiones sobre su legitimidad, dos problemas que enfrentó la normativa del proceso de integración. En este marco, el artículo da cuenta de los principales conflictos surgidos a raíz de restricciones no arancelarias aplicadas por Argentina contra la importación de Brasil durante diez años. Evidencia que si tempranamente la normativa del MERCOSUR definió las restricciones como instrumentos ilegítimos en el proceso de integración, el escaso avance que hubo en el establecimiento de instrumentos regionales para abordarlas hizo que las restricciones se fueran naturalizando como parte del proceso. La insatisfacción tanto con los mecanismos de consultas regionales como con el sistema de solución de controversias hizo que la mayoría de aquellos conflictos fueran negociados de manera bilateral, perpetuándose un círculo vicioso entre la debilidad de aquellos instrumentos normativos regionales y la preferencia de los líderes nacionales por negociar las restricciones a nivel político.

Palabras clave: MERCOSUR - restricciones no arancelarias - Argentina

\section{Argentinean Non-Tariff Barriers in MERCOSUR: Regulations and Politics in Trade Conflicts}

Luciana GIL

\begin{abstract}
This article deals with non-tariff barriers as a permanent problem in MERCOSUR. First, it analyses the international definition of "barriers", which creates difficulties to identify them and generates discussions on their legitimacy. It shows that MERCOSUR regulations faced also both problems. Second, the article addresses the main conflicts emerged from non-tariff barriers imposed by Argentina against Brazilian imports. It demonstrates that MERCOSUR regulations early defined non-tariff barriers as illegitimate instruments in the integration process, but because of the lack of effective regional mechanisms to deal with them, they became ordinary. The dissatisfaction of different agents with the performance of the consultative mechanisms and the regional court had as a consequence a bilateral approach to trade conflicts, perpetuating the relation among weak regional regulations and preferences of national leaders for political negotiations as a vicious cycle.
\end{abstract}

Key words: MERCOSUR - non-tariff barriers - Argentina

TRABAJO RECIBIDO: 24/08/2015

ACEPTADO: 27/09/2015

\footnotetext{
* Agradezco el apoyo del Consejo Nacional de Investigaciones Científicas y Técnicas (CONICET) para realizar la investigación doctoral que da origen a este artículo.

** Doctora en Ciencias Sociales (Universidad de Buenos Aires, Instituto de Investigaciones Gino Germani). Correo electrónico: lucianavgil@yahoo.com.ar
} 


\section{Las restricciones no arancelarias argentinas en el MERCOSUR: normas y política en los conflictos comerciales}

\section{ÍNDICE}

Introducción

1. La liberalización comercial en el MERCOSUR: reducción arancelaria y restricciones no arancelarias

2. Restricciones no arancelarias: problemas y ventajas de una definición imprecisa

3. Las restricciones no arancelarias en la normativa MERCOSUR: avances y limitaciones

4. Un recorrido por las restricciones no arancelarias argentinas en el MERCOSUR (1999-2008)

Reflexiones finales 


\section{INTRODUCCION}

Durante sus primeros años, al MERCOSUR se le atribuyó un considerable éxito en términos de aumento del intercambio comercial intrarregional ${ }^{1}$, pero desde fines de siglo, las crisis económicas atravesadas por los países que lo conforman y la contracción del comercio intrazona avivaron las referencias a un proceso "estancado", con diversas dificultades para avanzar en la integración proyectada y para diseñar una estrategia sostenida de desarrollo. Las restricciones al comercio intrarregional se apuntaron como algunas de las más directas expresiones de aquel "estancamiento", ya que no permitirían consolidar ni la zona de libre comercio en la región, ni la unión aduanera. Tal señalamiento se observa en artículos tanto de difusión periodística como académica que, sin embargo, hacen poco por comprender la compleja trama de causas de dichas restricciones y tampoco se interrogan acerca de las consecuencias que éstas pueden tener en un ámbito distinto del estrictamente económico.

Este artículo se presenta como un primer paso para encarar tales reflexiones. Su universo se limita a las restricciones no arancelarias argentinas, que han sido un elemento permanente en la agenda de liberalización comercial desde los inicios del MERCOSUR. Las analiza no como fenómeno exclusivo de este proceso de integración, sino como tema que fue adquiriendo mayor importancia a nivel mundial a medida que se reducían los aranceles al comercio internacional. Observa que la propia definición de "restricción" o "barrera" no arancelaria (en adelante, RNA) dificulta su identificación y genera discusiones sobre su legitimidad a nivel internacional, dos problemas que también enfrentó la normativa del MERCOSUR al intentar avanzar en su eliminación o armonización.

En este marco, el artículo da cuenta del recorrido normativo que realizó el proceso de integración para abordar este problema y resume la historia de las RNA argentinas exponiendo los principales conflictos comerciales que han causado con Brasil, así como la forma en que fueron abordados. El análisis de ambas dimensiones, normativa e histórica, muestra la preeminencia de la negociación política y reflexiona acerca de las dinámicas que ésta ha favorecido.

El texto se refiere a un período de diez años, desde el fin del "Régimen de adecuación final a la unión aduanera" en 1999 hasta 2008, cuando Argentina comenzó a sufrir los primeros efectos de la crisis económica y financiera internacional. Esto permite observar los distintos contextos económicos en los que los conflictos comerciales se han enmarcado: un período que se identificó como la primera crisis del intercambio comercial (en coincidencia con crisis económicas de los dos países más grandes del bloque entre 1999 y 2001); y otro en el que se combinó el renovado crecimiento económico de los países con ciertas iniciativas regionales que buscaban generar un perfil del proceso de integración más productivo que comercial

\footnotetext{
${ }^{1}$ El incremento del intercambio comercial intra-MERCOSUR, desde su creación, alcanzó su máximo en 1998 (cuando su participación en el comercio total del MERCOSUR alcanzó casi el 25\%), para contraerse a partir de 1999 y llegar a su punto mínimo en 2002 (11,5\%). Recién a partir de 2003 recuperó su crecimiento, aunque nunca volvió a alcanzar el nivel de 1998. Ver gráfico 1.
} 
(2002-2008). Exponer estos diferentes contextos muestra que, si bien las RNA se justificaron en principio como protecciones temporales excepcionales necesarias por la situación de crisis, luego se mantuvieron en momentos de crecimiento, transformándose en elementos constantes del proceso de integración.

El artículo evidencia que si tempranamente la normativa del MERCOSUR definió las RNA como instrumentos ilegítimos en el proceso de integración, el escaso avance que hubo en su identificación, así como en el establecimiento de mecanismos regionales para abordarlas, produjo dos situaciones paralelas. Por un lado, hizo que las RNA se fueran naturalizando como parte del proceso; por el otro, al ser contrarias a las normas del MERCOSUR, su permanencia alimentó continuamente las críticas al bloque. Para llegar a esta situación convergieron elementos que tuvieron que ver con la dificultad de identificación de las RNA, con la insatisfacción con los mecanismos de consultas a la Comisión de Comercio del MERCOSUR (CCM) y con el sistema de solución de controversias. Como consecuencia, un sinnúmero de aquellos conflictos fue negociado a nivel político y bilateral, algo que, en forma de círculo vicioso, debilitó, a su vez, los intentos de desarrollar instrumentos normativos regionales para abordar las RNA.

\section{LA LIBERALIZACIÓN COMERCIAL EN EL MERCOSUR: REDUCCIÓN ARANCELARIA Y RESTRICCIONES NO ARANCELARIAS}

El proceso de integración del MERCOSUR se inició con un marcado énfasis en su dimensión comercial, luego de los intentos integracionistas de los años $60^{2}$ y de las experiencias frustradas de los acuerdos sectoriales entre Argentina y Brasil a fines de los ' $80^{3}$. En julio de 1990, ambos países suscribieron el Acta de Buenos Aires y, en diciembre del mismo año, el Acuerdo de Complementación Económica № 14 en el marco de la Asociación Latinoamericana de Integración (ALADI). Estos dos documentos dieron las bases instrumentales para el proceso de integración que inauguraría el Tratado de Asunción en 1991.

El primer considerando de este Tratado señalaba que la ampliación de los mercados nacionales era "condición fundamental para acelerar" los procesos de "desarrollo económico con justicia social” de los Estados Partes. El Tratado disponía, además, en su $7^{\circ}$ artículo, que "en materia de impuestos, tasas y otros gravámenes internos, los productos originarios del territorio de un Estado Parte gozarán, en los otros Estados Partes, del mismo tratamiento que

\footnotetext{
2 Para una revisión general actualizada de la integración regional latinoamericana, ver: Briceño Ruiz, José; Rivarola Puntigliano, Andrés; y Casas Gragea, Ángel María, Integración latinoamericana y caribeña: política y economía, Fondo de Cultura Económica, Madrid, 2012.

${ }^{3}$ Argentina y Brasil iniciaron sus primeros pasos de integración bilateral con la Declaración de lguazú y la Declaración Conjunta de Cooperación Nuclear firmadas a fines de 1985, en ocasión de la inauguración del puente "Tancredo Neves". Allí se procuraba comenzar un proceso de integración económica, comercial, de transportes, comunicaciones, científica, tecnológica, energética y nuclear a partir de doce protocolos de integración sectorial que se firmarían a continuación. La negociación de estos protocolos había dado algunos pasos en cuanto a la eliminación de restricciones no arancelarias, requisitos administrativos y sistemas de consulta previa, pero fueron muy pocos hasta la firma del Tratado de Asunción en 1991. Ver Campbell, Jorge (ed.), MERCOSUR. Entre la realidad y la utopía, Grupo Editor Latinoamericano, Buenos Aires, 1999, pág.129-130. Ver también la obra de Lavagna, Roberto, Argentina, Brasil, MERCOSUR. Una Decisión Estratégica 1986-2001, Ciudad Argentina, Buenos Aires, 1998.
} 
se aplique al producto nacional". Entre otras cosas, se esperaba que la liberalización comercial diera lugar a un mercado regional que permitiera aumentar el intercambio, aprovechar las economías de escala en la producción y adecuar la competitividad de las economías de los Estados a los más altos estándares internacionales ${ }^{4}$.

Por eso, Argentina, Brasil, Paraguay y Uruguay suscribían el compromiso de formar un Mercado Común para 1995 que implicaría:

- la libre circulación de bienes, servicios y factores productivos entre los países, a través de, entre otros elementos, la eliminación de los derechos aduaneros y restricciones no arancelarias;

- un arancel externo común y una política comercial común con relación a terceros Estados o agrupaciones de Estados y la coordinación de posiciones en foros económicos comerciales regionales e internacionales;

- la coordinación de políticas macroeconómicas y sectoriales de comercio exterior, agrícola, industrial, fiscal, monetaria, cambiaria y de capitales, de servicios, aduanera, de transportes y comunicaciones y "otras que se acuerden a fin de asegurar condiciones adecuadas de competencia";

- el compromiso de los Estados Partes de armonizar sus legislaciones en las áreas pertinentes ${ }^{5}$.

De esta serie de herramientas para alcanzar su objetivo de desarrollo, el diseño del proceso de integración priorizó claramente la desgravación arancelaria para el intercambio comercial intrarregional y el establecimiento de un arancel externo común ${ }^{6}$. Para el primero, que es el tema de este trabajo, preveía un programa de desgravación progresivo, lineal y automático de la mayoría de productos ${ }^{7}$. Además, durante un primer período de transición (1991-1994), los Estados Partes adoptaban ciertos mecanismos para limitar las importaciones de otros Estados Partes, que se podrían aplicar hasta el 31 de diciembre de 1994, sólo "en casos excepcionales": : un Régimen general de origen, un Sistema de solución de controversias y

\footnotetext{
${ }_{5}^{4}$ Campbell, Jorge, op. cit., pág. 131.

${ }^{5}$ Tratado de Asunción, artículo 1.

${ }^{6}$ Otras eran: la política comercial común con relación a terceros estados o agrupaciones de estados y la coordinación de posiciones en foros económicos comerciales regionales e internacionales; la coordinación de políticas macroeconómicas y sectoriales de comercio exterior, agrícola, industrial, fiscal, monetaria, cambiaria y de capitales, de servicios, aduanera, de transportes y comunicaciones y "otras que se acuerden a fin de asegurar condiciones adecuadas de competencia"; y el compromiso de los Estados Partes de armonizar sus legislaciones en las áreas pertinentes (Tratado de Asunción, art. 1).

${ }^{7}$ EI ACE 14 firmado en 1990 permitía a los países exceptuar hasta 300 bienes "sensibles" de la dinámica de desgravación progresiva. Los productos exceptuados por Argentina fueron toda la gama de azúcares, varias de café, de productos de siderurgia, aparatos de audio, video y radiotelefonía, textiles, papeles y calzados (ACE 14, Anexo III). Varios de ellos mantendrían en el futuro la excepción al arancel externo común, formarían parte del Régimen de adecuación, o contarían con otro tipo de barreras, como licencias no automáticas.

${ }^{8}$ Tratado de Asunción, Anexos II, III y IV. EI mecanismo de salvaguardias podía aplicarse sólo si "las importaciones de determinados productos causaran daño o amenaza de daño grave a su mercado, como consecuencia de un sensible aumento de las importaciones de ese producto en un corto período". Este daño se evaluaba en función de niveles de producción, empleo, participación en el mercado y desempeño del comercio exterior en relación a otros países, y la salvaguardia podía implementarse sólo luego de consultas con el país exportador y el Grupo Mercado Común, y sólo si allí no se conseguía un acuerdo sobre cuotas (anuales y renovables). De todas maneras, se establecía que "en ningún caso la aplicación de cláusulas de salvaguardia" podía "extenderse más allá del 31 de diciembre de 1994". Cabe destacar la similitud de este mecanismo de consultas previo a la salvaguardia con el Mecanismo de Adaptación Competitiva que se acordaría en 2006 , como se verá en las próximas secciones.
} 
Cláusulas de salvaguardia. En su Anexo I, el Tratado señalaba: "los Estados Partes acuerdan eliminar a más tardar el 31 de diciembre de 1994 los gravámenes y demás restricciones aplicadas en su comercio recíproco", entendiendo por restricciones "cualquier medida de carácter administrativo, financiero, cambiario o de cualquier naturaleza, mediante la cual un Estado Parte impida o dificulte, por decisión unilateral, el comercio recíproco"9. De estas reglas generales quedaría exceptuado el comercio automotriz y azucarero, una excepción en principio temporal que, sin embargo, se extendería en el tiempo.

El Tratado de Asunción preveía una estructura institucional básica para lograr sus objetivos, formada por:

- el Consejo de Mercado Común (CMC, integrado por Ministros de Relaciones Exteriores y de Economía de los Estados Partes, con presidencia rotativa), que tendría "la conducción política del mismo y la toma de decisiones para asegurar el cumplimiento de los objetivos y plazos establecidos para la constitución definitiva del mercado común"; y

- el Grupo de Mercado Común (GMC) como órgano ejecutivo (constituido por miembros de los Ministerios de Relaciones Exteriores; de Economía y de bancos centrales), que tendría facultad de iniciativa. Además, debería velar por el cumplimiento del Tratado y de las decisiones adoptadas por el Consejo; proponer medidas para la liberación comercial, la coordinación de políticas macroeconómicas y la negociación de acuerdos frente a terceros; y fijar el programa de trabajo hacia la constitución del mercado común. EI GMC podría crear Subgrupos de Trabajo y "convocar, cuando así lo juzgue conveniente, a representantes de otros organismos de la Administración Pública y del Sector Privado" ${ }^{\prime 10}$. Por último, el Grupo contaría con una Secretaría Administrativa con sede en Montevideo.

En 1994, concluido el mencionado período de transición, y luego de arduas negociaciones, los líderes de los cuatro países del MERCOSUR, reunidos en Ouro Preto, decidieron poner en marcha la unión aduanera, avanzando en el establecimiento de un arancel externo común. En lo que respectaba al comercio intrarregional, se estableció el Régimen de adecuación final a la unión aduanera ${ }^{11}$. Éste se extendería por otros cuatro años (Argentina y Brasil) o cinco (Paraguay y Uruguay), durante los cuales se permitía mantener aranceles o cuotas a la importación de determinados productos, pero con un cronograma fijo que los reducía gradualmente $^{12}$. Es decir, se mantenía el objetivo del libre comercio para estos sectores, pero se les brindaba, de manera acordada entre los cuatro países, un plazo mayor al que habían

\footnotetext{
9 Tratado de Asunción, Anexo I, artículos 1 y 2. En el concepto de "restricciones" no quedaban comprendidas "las medidas adoptadas en virtud de las situaciones previstas en el artículo 50 del Tratado de Montevideo de 1980", referido a la protección de la moralidad pública; la aplicación de leyes y reglamentos de seguridad; la regulación del comercio de materiales de guerra; la protección de la vida y salud de las personas, los animales y los vegetales; el comercio de oro y plata metálicos; la protección del patrimonio nacional de valor artístico, histórico o arqueológico; y la exportación, utilización y consumo de materiales nucleares, productos radiactivos o cualquier otro material utilizable en el desarrollo 0 aprovechamiento de la energía nuclear.

${ }_{11}$ Tratado de Asunción, artículo 14.

${ }^{11}$ Decisiones № $5 / 94$ y 24/94.

12 Para ser seleccionados, estos productos debían haber figurado en las primeras excepciones al Tratado de Asunción o haber sido objeto de medidas de salvaguardia durante el período de transición.
} 
tenido los demás para que sus aranceles de importación llegaran a $0^{13}$.

El cronograma previsto por el Régimen de adecuación fue cumplido a rajatabla, por lo tanto, en el año 2000 todos los productos de la lista tenían arancel 0 para la importación intrazona. Sin embargo, otras decisiones orientadas al comercio intrarregional y a la consolidación de la unión aduanera no avanzaron ${ }^{14}$ y proliferaron, paralelamente, las denuncias por restricciones al comercio (ahora, no arancelarias) que, con el correr de los años, fueron motivo de quejas formales e informales, conflictos políticos y laudos arbitrales. De esta manera, el proceso de integración estuvo caracterizado por dos tendencias paralelas: por un lado, una progresiva reducción de aranceles orientada a facilitar el comercio entre los socios; por el otro, el uso de otros mecanismos (no arancelarios) que, en ciertos productos, obstaculizaban dicho comercio y fomentaban las referencias al MERCOSUR como una unión aduanera imperfecta o hasta un área de libre comercio imperfecta, en la que el compromiso sobre la eliminación de restricciones no arancelarias se había diluido ${ }^{15}$.

\section{RESTRICCIONES NO ARANCELARIAS: PROBLEMAS Y VENTAJAS DE UNA DEFINICIÓN IMPRECISA}

Son varios los autores que consideran las RNA una consecuencia natural del aumento del intercambio comercial y de la creciente imposibilidad jurídica de utilizar aranceles para proteger al mercado importador. Aquella imposibilidad jurídica (que, evidentemente, no es absoluta), a nivel internacional, se debe a las regulaciones de la Organización Mundial de Comercio (OMC) que tienden a eliminar los aranceles ( $y$, con ellos, una importante fuente de recaudación del Estado), o también a los acuerdos de libre comercio, que hacen lo mismo a nivel regional y/o bilateral. De allí que, a medida que progresó la reducción de los aranceles, aumentó la utilización de restricciones no arancelarias $^{16}$, al punto de que varios autores coinciden en

\footnotetext{
${ }^{13}$ Los productos con mayor presencia en la lista argentina del Régimen de adecuación fueron metales, prendas de vestir, pasta de madera, papel y cartón; y calzados.

${ }^{14}$ Como por ejemplo la Decisión № 10/94, relativa a los incentivos a las exportaciones intrazona o la Decisión № 21/94, que definió una serie de principios básicos para guiar la defensa de la competencia. Bouzas, Roberto, Mecanismos para compensar los efectos de las asimetrías de la integración regional y la globalización: Lecciones para América Latina y el Caribe. El caso del MERCOSUR, Documento preparado para el seminario "Global y Local: El Desafío del desarrollo regional en América Latina y el Caribe”, Milán (Italia), 22 de marzo de 2003.

15 Baruj, Gustavo; Porta, Fernando, "Políticas de competitividad en la Argentina y su impacto en la profundización del MERCOSUR", CEPAL, Documento de trabajo, julio de 2006 y Peña, Félix, "Los Grandes Objetivos Del MERCOSUR: Zona de Libre Comercio, Unión Aduanera Y Mercado Común", Presentación al Seminario: "15 Anos do MERCOSUL: avaliaçao e perspectivas", Fundaçao Memorial Da América Latina, Sao Paulo, 17 de marzo de 2006. Los estudios de integración suelen diferenciar entre zona de libre comercio (que implica el libre intercambio de bienes entre las economías que la componen), unión aduanera (que agrega a ese intercambio el establecimiento de un arancel externo común para el comercio con terceros países) y mercado común (que implica, además de los anteriores, el libre intercambio de servicios y personas), entre otras situaciones de integración económica. Balassa, Béla, "Hacia Una Teoría de la Integración Económica," en Wionczek, Miguel, Integración de América Latina, Fondo de Cultura Económica, México, 1964.

${ }^{16}$ El promedio de aranceles aplicados a bienes cayó del 40\% en 1947 al 5\% en 1994 . Barral, Welber, O Brasil e o Protecionismo, Aduaneiras, Sao Paulo, 2002, pág. 16. Tradicionalmente, los aranceles eran no sólo instrumentos del estado para regular el comercio, sino también fuente de recaudación, algo que las RNA posteriores no siempre pueden ser (por ejemplo, cuando se trata de requerimientos técnicos que no implican ninguna erogación al estado).
} 
señalar que muchos Estados "adoptaron un discurso liberal y una práctica proteccionista", pretendiendo "usufructuar los beneficios del libre comercio, sin afrontar los riesgos de exponer sus economías a la competencia externa"17. En realidad, la OMC también prohíbe toda otra medida que restrinja el comercio de manera no arancelaria, y sólo la permite en situaciones especiales. Por eso, hay medidas proteccionistas autorizadas y otras prohibidas según estas situaciones. Sin embargo, como se verá enseguida, el criterio de prohibición no es taxativo, lo que dificulta su identificación y cuestionamiento, permitiendo que los Estados utilicen esas medidas amplia e imaginativamente ${ }^{18}$. La misma dificultad complica la eliminación de este tipo de barreras, mucho más compleja que en el caso de los aranceles.

Los motivos por los cuales los Estados pueden recurrir a limitar el comercio por esta vía son variados. Entre ellos figura el cálculo económico mencionado: aprovechar la apertura del comercio para exportar pero limitando la importación que pueda perjudicar la estructura productiva interna, en términos de niveles de producción y/o de empleo. Pero también se incluye el control de la calidad de los productos que ingresan a un país (en general ligados a proteger la salud de sus habitantes) ${ }^{19}$. Otros motivos pueden tener que ver con fines estadísticos, de información de los productos, de cumplimiento con normas medioambientales, o de protección temporaria de productores locales para que alcancen niveles de competitividad que les permitan, luego, competir con sus pares internacionales. Dentro de esta variedad, los efectos de las RNA han sido ponderados como positivos o negativos, según el sector en cuestión, el contexto económico nacional e internacional y las prácticas a las que den lugar. Así, por ejemplo, algunos autores argentinos han rescatado la importancia de la limitación del comercio por parte del Estado, para que éste oriente el desarrollo económico (por ejemplo, ayudando a sectores incipientes ${ }^{20}$; otros han subrayado las características discriminatorias de estas limitaciones, vinculándolas con la corrupción y la decadencia económica ${ }^{21}$. Este trabajo no ofrece una valoración de este tipo sobre las RNA en el MERCOSUR, sino que se limita a marcar el doble filo de una definición jurídica imprecisa, ya que ésta puede acarrear problemas de identificación y abordaje, pero también brinda un margen significativo para negociaciones de carácter político y discrecional sobre estas medidas.

Se habla de imprecisión porque la OMC define las RNA de una manera formal y no sustancial. Para la organización, se trata de "cuestiones legales o burocráticas que pueden implicar obstáculos al comercio”,22. Por su parte, la literatura sobre comercio internacional ha tendido a

\footnotetext{
${ }^{17}$ Lacerda Prazeres,Tatiana, Comércio Internacional e Protecionismo. As Barreiras Técnicas na OMC, Aduaneiras, Sao Paulo, 2003, pág. 5 y 16. Sobre la misma idea como fuente de la contradicción que estudia la economía política internacional, ver Gilpin, Robert, La Economía Política de las Relaciones Internacionales, GEL, Buenos Aires, 1990.

${ }^{18}$ Barral, Welber, op. cit., pág. 15. Sobre la amplia utilización de estas medidas a nivel internacional, ver también Lacerda Prazeres,Tatiana, op. cit. y Deardorff, Alan V.; Stern, Robert Mitchell, Measurement of Nontariff Barriers, University of Michigan Press, 1998. Sobre un resumen de estas restricciones en los países sudamericanos (y México) previas al inicio del MERCOSUR, ver Valenzuela, Juan Guillermo, "Restricciones No Arancelarias en los países de la ALADI," Integración Latinoamericana, Vol. 9, № 87, enero-febrero de 1984.

${ }_{19}^{19}$ Lacerda Prazeres, Tatiana, op. cit., pág. 5 y 16.

${ }^{20}$ Bekerman, Marta; Sirlin, Pablo, "Nuevos enfoques sobre política comercial y sus implicancias para los países periféricos", Desarrollo Económico, Vol. 3, No. 134, septiembre de 1994.

${ }^{11}$ Nogués, Julio J., "La economía política del proteccionismo y la liberalización en la Argentina", Desarrollo Económico, Vol. 28, № 110, septiembre de 1988.

${ }^{22}$ E identifica entre ellas licencias de importación, valoración en aduana, inspecciones previas, reglas de origen y requerimientos de inversión que afecten el comercio. Ver OMC, disponible en:
} 
tratarlas como categoría residual, a partir de una definición negativa, es decir, aquello que no son: todas las medidas que restringen el comercio sin ser aranceles ${ }^{23}$. De ahí que puedan considerarse RNA todas las leyes gubernamentales, regulaciones, políticas y prácticas (excepto aranceles), que restringen el acceso de productos importados a los mercados domésticos o que artificialmente incentivan las ventas externas, como los subsidios a la producción y a las exportaciones ${ }^{24}$.

Como se adelantó, la OMC regula la forma y los requerimientos que un gobierno debe cumplir para que algunas medidas burocráticas o legales sean aceptadas por la organización ${ }^{25}$, ya que, en principio, el artículo XI del GATT prohíbe toda barrera al comercio que no sea arancel, impuestos $u$ otros cargos, buscando que las restricciones sean expresadas sólo en aranceles (ya que son más fáciles de identificar y, a partir de ello, negociar). Pero el principal problema de este artículo ha sido históricamente su interpretación, que da lugar a dudas sobre ciertas restricciones. Por ejemplo, los precios mínimos o requerimientos de inversión, sobre los cuales el GATT, y luego la OMC, han debido interpretar caso por caso, inclinándose a establecer excepciones (como para agricultura, vestimenta y textiles, acero) ${ }^{26}$. Además, existe una serie de excepciones previstas en otros artículos del GATT, sobre motivos que autorizan este tipo de medidas (desabastecimiento, art. XI; problemas de balanza de pagos, art. XII y XVIII; protección de la salud pública, vegetal, art. XX; seguridad, art. XXI; y medidas de salvaguardia, art. XIX). También se prevén excepciones para los países en desarrollo, a quienes se les permite establecer restricciones cuantitativas por motivos de desequilibrio de su balanza de pagos, siempre que den cuenta del aumento de importaciones como consecuencia de sus programas de desarrollo económico (art. XVIII).

La amplitud de la definición y de las posibles interpretaciones de estos artículos hace muy difícil establecer un criterio estricto para catalogar como RNA algunas medidas ya que, aunque su efecto en el comercio sea claro, pueden ser justificadas como políticas estratégicas con variados objetivos, que no necesariamente son limitar comercio ni discriminar productos extranjeros $^{27}$. Así, la línea que limita la legitimidad de estos procedimientos y disposiciones es muy difusa, puesto que es difícil establecer un criterio unívoco que diferencie procedimientos idóneos de procedimientos excesivos destinados a trabar las importaciones. Esa línea delgada también muestra la dificultad de separar los objetivos "legítimos" de los "no legítimos", una tarea política que está relacionada con la construcción de la realidad a través de las definiciones y las interpretaciones que los actores hacen sobre estas medidas. Así, al igual que

http://www.wto.org/english/thewto e/whatis e/tif e/agrm9 e.htm [consulta: 3 de agosto de 2015].

${ }^{23}$ Deardorff, Alan V.; Stern, Robert Mitchell, op. cit., pág. 3.

${ }^{24}$ Que en realidad no son una barrera al comercio sino, por el contrario, un estímulo. Ibid. El artículo XVI del GATT define a las subvenciones como contribuciones financieras de un gobierno o de cualquier organismo público de ese gobierno que de alguna forma sostenga ingresos o precios, aunque solo quedan sujetas a sus disposiciones aquellas contribuciones definidas como "específicas": aquellas obtenibles por una empresa, rama, grupo de empresas o de ramas dentro de la jurisdicción de la autoridad que otorga la subvención. El texto completo del GATT 1947 y su versión 1994 están disponibles en: http://www.wto.org/english/res e/booksp e/analytic index e/gatt1994 e.htm [consulta: 3 de agosto de 2015]. Ver también Ablin, Eduardo; Makuc, Adrián, Comercio Exterior, Errepar, Buenos Aires, 1997, 124.

${ }^{25} \mathrm{OMC}$, disponible en: http://www.wto.org/english/thewto e/whatis e/tif e/agrm9 e.htm [consulta: 3 de agosto de 2015].

${ }^{26}$ Jackson, John H.; Davey, Williams J.; Sykes Jr., Alan O. , Legal Problems of International Economic Relations. Cases, Materials and Text, West Group, American Casebook Series, St. Paul, Minnesota, 2002. ${ }^{27}$ Ibidem 
sucede a nivel internacional, a lo largo de la historia del MERCOSUR, las RNA para el comercio intrazona se encontraron en un área gris entre lo permitido y lo no permitido. En el bloque sudamericano, la concentración inicial en la liberalización comercial respondía a una interpretación que iba en línea con el ideal del libre comercio institucionalizado en la OMC; pero, a medida que el proceso de integración se desarrollaba, hacía expresa la falta de una interpretación común sobre el tema.

Pese a esta amplia definición, en la literatura se ha intentado clasificar las RNA de acuerdo a los motivos que las originan: políticas de importación, regulaciones sanitarias y fitosanitarias, obstáculos o requerimientos técnicos, medidas de protección ambiental, políticas públicas discriminatorias, y de productos especiales (seguridad nacional) ${ }^{28}$. Dada la dificultad de realizar una verdadera clasificación de estas medidas que las distinga a partir de categorías excluyentes $^{29}$, otros autores se concentran en el análisis de la variopinta forma que toman estas restricciones, algunas ejerciendo efectos directos sobre cantidades, costos y precios de las importaciones; otras afectándolos de manera indirecta.

Entre las primeras, se identifican prohibiciones de importación, cuotas, licencias de importación no automáticas, derechos compensatorios y antidumping, precios mínimos de importación y restricciones voluntarias de exportación ${ }^{30}$. Entre las segundas, algunos autores incluyen restricciones no arancelarias informales, esto es, medidas gubernamentales no publicadas, que pueden ser resultado de esfuerzos conscientes por parte de un gobierno para favorecer intereses locales o simplemente una consecuencia de prácticas y políticas enraizadas en instituciones internas $^{31}$. En este sentido, se incluirían como restricciones no arancelarias hasta instituciones políticas, sociales y culturales que "escapan a la legalidad, que no tienen normativa y que significan costos adicionales a la importación como los costos de la corrupción, que para algunos países es relevante"32. Así, hay pocas posibilidades de que una tipología de RNA sea exhaustiva ${ }^{33}$, por lo que aquí sólo se pretende hacer referencia a las principales RNA argentinas que se han identificado en el período de estudio y que han causado conflictos comerciales con Brasil, analizados en la sección 4.

Los principales conflictos que han aparecido en ese recorrido surgieron a raíz de restricciones que, en su mayoría, han tomado las siguientes formas:

1) restricciones cuantitativas y otros instrumentos similares. Por ejemplo, cuotas a las importaciones, restricciones voluntarias a las exportaciones (en general alcanzadas por medio de acuerdos entre privados ${ }^{34}$ ) y licencias de importación, llamadas oficialmente también de otras formas, como certificados de importación, que son autorizaciones requeridas antes de

28 Sanguinetti, Pablo; Sallustro, Marina, MERCOSUR y el sesgo regional de la política comercial: Aranceles y barreras no tarifarias, Centro de Estudios para el Desarrollo Institucional, marzo de 2000.

${ }^{29}$ Esta dificultad puede verse en la clasificación sugerida por Centurión López, Aldo, "Restricciones no arancelarias en el MERCOSUR", presentación para el Seminario: "Los nuevos desafíos para la integración regional", BID/INTAL, Buenos Aires, 2 y 3 de octubre del 2002, 4. Allí el autor las distingue entre "efectos cuantitativos y a través de costos y precios" y "otras restricciones no arancelarias", en las que incluye "procedimientos, normativa interna protección de la salud, medio ambiente y seguridad".

${ }^{30}$ Sanguinetti, Pablo; Sallustro, Marina, op. cit.

${ }^{31}$ Deardorff, Alan V.; Stern, Robert Mitchell, op. cit., pág. 3-4.

${ }^{32}$ Centurión López,Aldo,op. cit., pág. 3.

${ }^{33}$ Deardorff, Alan V.; Stern, Robert Mitchell, op. cit., pág. 3.

${ }^{34}$ Vale aclarar que este instrumento no es reconocido por la OMC, pero, como se verá más adelante, ha sido ampliamente utilizado y promovido por la Comisión Bilateral Argentina-Brasil en el marco del MERCOSUR. Informe MERCOSUR, №15, BID/INTAL, Buenos Aires, febrero 2011, pág. 121. 
cada importación y que deben ser emitidas por el importador;

2) medidas que afectan directamente los precios. Por ejemplo, medidas antidumping y salvaguardias ${ }^{35}$, derechos de importación ad valorem o específicos ${ }^{36}$, precios mínimos o valores criterio (por debajo de los cuales no se puede realizar la importación);

3) procedimientos aduaneros y prácticas administrativas. Por ejemplo, valuación en aduana yaduanas especializadas (fuera de las cuales no podía ingresar el producto);

4) barreras técnicas al comercio. Por ejemplo, estándares, registro yrequerimientos de etiquetado con información de origen y materiales (sin la cual el producto no puede ingresar al país) ${ }^{37}$.

\section{LAS RESTRICCIONES NO ARANCELARIAS EN LA NORMATIVA MERCOSUR: AVANCES Y LIMITACIONES}

Al igual que a nivel internacional, dentro del MERCOSUR la mayoría de las RNA están prohibidas. Como se mencionó, se permitieron ciertas salvaguardias hasta $1994^{38}$, así como derechos antidumping y compensatorios, entendidos como instrumentos de defensa comercial, siempre que se cumpliera con las investigaciones establecidas ${ }^{39}$. Las otras restricciones, en cambio, están formalmente prohibidas para el comercio intrazona, salvo en los casos previstos por el artículo 50 del Tratado de Montevideo de 1980. Sin embargo, como se verá en la

\footnotetext{
${ }^{35}$ Las medidas de salvaguardia se definen como medidas "de urgencia" con respecto al aumento de las importaciones de determinados productos cuando esas importaciones hayan causado o amenacen causar un daño grave a la rama de producción nacional del importador. Esas medidas, que en general adoptan la forma de suspensión de concesiones u obligaciones, pueden consistir en restricciones cuantitativas de las importaciones o aumentos de los derechos por encima de los tipos consolidados. Los derechos antidumping son valores adicionales que los gobiernos establecen a productos que ingresan al país en condiciones de dumping, es decir, que son exportados por una empresa de otro país a un precio inferior al que aplica normalmente en el mercado de su propio país. Dado que esto puede dañar una rama de producción nacional, se lo considera una práctica de competencia desleal, y por eso, siguiendo las normas de la OMC, los países pueden iniciar investigaciones que resulten, en caso de confirmarse el daño, en la aplicación de un derecho de importación adicional al producto en cuestión, para lograr que el precio de dicho producto se aproxime al "valor normal" o para suprimir el daño causado a la rama de producción nacional en el país importador. En Argentina, desde el Código Aduanero, ley 22.415 de 1981, se establecía que la formulación de la denuncia podía iniciarse por los afectados, por las dependencias de la administración pública o provincial o, de oficio, por la autoridad de aplicación, en ese momento definida como el Ministerio de Economía. En 1994 se creó la Comisión Nacional de Comercio Exterior, a la que se le atribuyeron funciones relativas a la determinación del daño o amenaza de daño en situaciones de importaciones bajo prácticas de dumping o subsidios y que adquiriría un papel importante en estos procedimientos. Ablin, Eduardo; Makuc, Adrián, op. cit.. Los derechos antidumping, los derechos compensatorios y las medidas de salvaguardia son tres tipos de medidas especiales de protección del comercio a las que pueden recurrir los miembros de la OMC. OMC, disponible en: http://www.wto.org/spanish/tratop s/safeg s/safeg info s.htm [consulta: 3 de agosto de 2015].

${ }^{36}$ Según el artículo 663 del Código Aduanero Argentino, los derechos específicos son un valor fijo por unidad o por kilo a pagar cuando el precio de importación más el arancel normal correspondiente está por debajo de un valor mínimo o "piso".

37 En base a Vaillant, Marcel, "Profundización del proceso de integración económica en bienes", en Chudnosvky, Daniel; Fanelli, José María (coordinadores), El desafío de integrarse para crecer, balances y perspectivas del MERCOSUR en su primera década, Red MERCOSUR, Siglo XXI, BID, Madrid, 2001. Ver también Centurión López,Aldo,op. cit., y Sanguinetti, Pablo; Sallustro, Marina, op. cit. La mayoría de las definiciones sobre cada tipo de medida está disponible en el Código Aduanero Argentino: http://www.infoleg.gov.ar/infoleglnternet/anexos/15000-19999/16536/texact.htm [consulta: 3 de agosto de 2015].

${ }^{38}$ Desde 1995 sólo son aplicadas para importaciones extrazona. La imposibilidad de utilizarlas dentro del MERCOSUR luego de 1995 quedó establecida en la decisión CMC №17/96.

${ }^{39}$ Informe MERCOSUR, BID/INTAL, Buenos Aires, junio de 1998.
} 
próxima sección, estuvieron presentes a lo largo de la historia del MERCOSUR y, en general, desataron consultas, reclamos y conflictos comerciales entre los socios. En muchos de los casos, las RNA se han caracterizado por la aparición repentina de requisitos de importación y, como consecuencia, la dificultad de cumplirlos a tiempo, lo que los constituía en obstáculos al comercio $^{40}$.

Como se señaló al inicio, el cronograma general de reducción de aranceles establecido a partir del Tratado Asunción concluyó en 1994. Dicho Tratado establecía que debían eliminarse también las RNA. En una primera etapa fueron identificadas y clasificadas, estableciéndose, en la decisión del CMC № 3/94, el procedimiento para su armonización y desmantelamiento antes del 31 de diciembre de $1994^{41}$. Ese año, a partir de la firma del Protocolo de Ouro Preto, se creó la Comisión de Comercio del MERCOSUR (CCM), cuya primera función sería "velar por la aplicación de los instrumentos comunes de política comercial intra-MERCOSUR y respecto de terceros países", incluyendo, entre otras tareas, "la eliminación y armonización de restricciones no arancelarias"42. Para afrontar estas tareas, crearía distintos Comités Técnicos, entre los cuales desde 1995 figuró el Comité Técnico № 8 (CT № 8) "Restricciones y medidas no arancelarias". En una reunión de Fortaleza de diciembre de 1996, el GMC encomendaba que se otorgara tratamiento prioritario a las tareas de eliminación y/o armonización de las RNA. Además, se instaba a todos los subgrupos y comités técnicos a que definieran antes del 31 de julio de 1997 la fecha en que las RNA identificadas podían ser eliminadas o armonizadas. Pero esto no pudo cumplirse ${ }^{43}$, por lo que en diciembre de 1997 se establecieron nuevos plazos para el año siguiente ${ }^{44}$. En 1998, este Comité identificó 262 restricciones no arancelarias en los cuatro países socios, de las cuales el $80 \%$ afectaba las importaciones. La dificultad de su eliminación o armonización permaneció; en parte, se atribuía al hecho de que, al ser normativas nacionales sobre estándares técnicos y las regulaciones sanitarias y fitosanitarias, requerían, para su aplicación, cambios en las leyes y regulaciones nacionales, los cuales, a su vez, demandaban tiempo para llevarlos a la práctica ${ }^{45}$. Sin embargo, la persistencia de estas restricciones hasta la actualidad muestra que no era ésta la única causa. Entre otras cosas, los autores mencionaban que "la resistencia dentro de los gobiernos y de sectores no gubernamentales", evitaban que se alcanzara el objetivo ${ }^{46}$.

Además de esta tarea de identificación que se atribuía a la Comisión, con las directivas 13/95 y

${ }^{40}$ Centurión López, Aldo, op. cit.

${ }^{41}$ Decisión CMC № 3/94, a partir del trabajo de identificación del Subgrupo de Trabajo № 1 "Asuntos comerciales". En la decisión se observa que fueron identificadas 31 medidas de este tipo en el conjunto de países. Se trató de un complejo ejercicio realizado por aquel Subgrupo de trabajo. Costa Vaz, Alcides, Cooperação, integração e processo negociador: a construção do MERCOSUL, IBRI, 2002, pág. 215. Una normativa nacional es armonizada cuando, originariamente en contradicción con el Tratado de Asunción, se modifica a partir del trabajo de los órganos técnicos correspondientes, de manera tal que todos los países miembros adopten un criterio unificado hacia la misma. Sanguinetti, Pablo; Sallustro, Marina, op. cit., pág. 12.

${ }^{42}$ Decisión CMC № 9/94. La creación de la Comisión de Comercio se debió al pedido argentino de mecanismos para suavizar las consecuencias de la entrada en vigencia de la unión aduanera: acuerdos de ajuste estructural, cláusulas de salvaguardia para el comercio intrarregional y la creación de dicha Comisión de Comercio. Sólo la última se realizó, dado que las dos anteriores fueron rechazadas por Brasil. Ver Lucángeli, Jorge, La inserción argentina en el MERCOSUR, Serie de Estudios, Centro de Estudios para el cambio estructural, septiembre de 1998.

${ }^{43}$ Informe MERCOSUR, №3, BID/INTAL, Buenos Aires, 1997, pág. 22.

${ }^{44}$ Decisión CMC № 17/97.

${ }^{45}$ Sanguinetti, Pablo; Sallustro, Marina, op. cit., y Vaz, op. cit., pág. 215.

${ }^{46}$ Vaz, op. cit., pág. 215-216. 
6/96 se estableció un mecanismo de consultas, por el cual cada parte podía presentar consultas a otros sobre materias que fueran competencia de la Comisión, entre ellas, las RNA. El mecanismo consistía básicamente en la presentación de la consulta, a partir de la cual el interpelado respondía y, si la respuesta era satisfactoria o la medida que causaba la consulta era levantada (sic), se daba por concluida la consulta. Sin embargo, si esto no sucedía "en la segunda reunión ordinaria de la CCM posterior a aquella en que fue presentada la Consulta", se preveía sólo que la CCM concluyera "en plenario la cuestión objeto de consulta en la siguiente reunión ordinaria". Más tarde, considerando que era "necesario adecuar los plazos para la consideración de las consultas en la CCM, a fin de conferir un tratamiento expeditivo a los cuestionamientos de orden comercial interpuestos por los Estados Partes", la directiva № 17/99 introdujo algunas modificaciones, aunque no fueron revolucionarias respecto de las directivas anteriores ${ }^{47}$. Así, el mecanismo siempre requería, para resolver la consulta, la voluntad del consultado de explicar o modificar la medida. Si esa voluntad no existía, la alternativa era recurrir al procedimiento de solución de controversias. Como se verá más adelante, tampoco este procedimiento garantizaría el enforcement de sus decisiones.

En su XVIII Reunión, el 29 de junio de 2000, el CMC consideró una agenda de trabajo prioritaria para lo que denominó el "Relanzamiento del MERCOSUR". En ese marco, "la persistencia de numerosas restricciones no arancelarias" en el comercio intrazona llevaba al Consejo del MERCOSUR a aprobar una decisión por la que los Estados Partes se comprometían a no adoptar "ninguna medida restrictiva al comercio recíproco, cualquiera sea su naturaleza" y a trabajar en la identificación de las principales medidas nacionales existentes para definir posteriormente "posibles cursos de acción para la superación de las dificultades" que las mismas ocasionaban ${ }^{48}$.

En diciembre del mismo año, la decisión 57/00 puso fecha límite a este trabajo (junio de 2001) ${ }^{49}$, pero a su vez, la decisión 59/00 modificó la estructura de la Comisión de Comercio, eliminando el CT № 8 dedicado a las $\mathrm{RNA}^{50}$. Otras decisiones tomadas en el marco del relanzamiento apuntaron a:

- la limitación del uso de incentivos a la producción y a la inversión (considerados generadores de distorsiones en la asignación de recursos en el ámbito subregional);

- el pronto relevamiento de los incentivos financieros y fiscales con incidencia en el

${ }^{47}$ El artículo 7 establecía que el estado parte consultante daría por "concluida" una consulta cuando la respuesta fuera considerada satisfactoria, o la causa que generó la consulta hubiera sido superada. Asimismo, podría dar por "concluida insatisfactoriamente" una consulta si su objeto no había sido resuelto y las posibilidades de solución en el ámbito de la CCM habían sido agotadas. El artículo 8 indicaba que, luego de transcurridas cuatro reuniones consecutivas de la CCM, a partir de la inclusión de una consulta en la categoría de Consulta en Plenario, las consultas serían dadas por "concluidas por expiración del plazo", salvo que el estado parte consultante y el consultado decidiesen lo contrario de común acuerdo. Finalmente, el artículo 11 señalaba que, si un estado parte recurría al Procedimiento General de Reclamaciones (Anexo al Protocolo de OuroPreto) o al Procedimiento de Solución de Controversias del Protocolo de Brasilia (tribunal arbitral), la formalización de esa reclamación o controversia daría por concluida insatisfactoriamente la referida consulta. Directiva CCM 17/99.

48 Decisión CMC № 22/00.

49 Decisión CMC № $57 / 00$.

${ }^{50}$ La estructura de la Comisión de Comercio quedaría establecida por los siguientes Comités Técnicos: CT-1 Aranceles Nomenclatura y Clasificación de Mercaderías; CT-2: Asuntos Aduaneros; CT-3: Normas y Disciplinas Comerciales; CT-4: Políticas Públicas que Distorsionan la Competitividad; CT-5: Defensa de la Competencia; CDCS: Comité de Defensa Comercial y Salvaguardias; y CT-7: Defensa del Consumidor. Decisión CMC №59/00. 
comercio intrazona (decisión № 31/00);

- disciplinar la aplicación de medidas antidumping y derechos compensatorios en el comercio intrazona (decisión № 28/00, prorrogada con la decisión № 64/00); y

- la prórroga de la vigencia de incentivos nacionales bajo la forma de regímenes aduaneros especiales, incluso para el comercio intrazona (decisiones 31/00 y 69/00).

Las metas de este "relanzamiento" fueron enseguida prorrogadas: en la XX Reunión del Consejo (Asunción, 22 de junio de 2001), la decisión № 7/01 extendió los plazos para resolver cuestiones sobre las medidas limitantes de acceso a los mercados y sobre los incentivos con efecto distorsivo sobre el comercio subregional. Lo mismo sucedió en la siguiente reunión (20 de diciembre de 2001) y en la otra (5 de julio de 2002). En diciembre de 2002, además, se fijó un régimen para el inicio de medidas de antidumping y compensatorias entre los Estados Partes $^{51}$. Recién en octubre de ese año se presentó un relevamiento que identificó 82 medidas no arancelarias que restringían el comercio intrazona, la mayoría de ellas aplicadas por Argentina y Brasil y con distintas modalidades: reglamentos técnicos, medidas fitosanitarias, falta de incorporación por parte de los países de la normativa subregional y procedimientos administrativos y aduaneros, entre otros. De los 28 casos presentados por Argentina, 18 correspondían a medidas impuestas por Brasil, mientras que de los 17 que éste presentó, 12 eran aplicados por Argentina ${ }^{52}$.

En 2004, el GMC emitió nuevas resoluciones para avanzar en la simplificación de los procedimientos de despacho aduanero y, al año siguiente, otra para la facilitación de comercio, dedicada a la resolución de conflictos puntuales de acceso al mercado de un país vecino, en especial debido a restricciones no arancelarias ${ }^{53}$. Estas resoluciones permitieron que en 2009 se aprobara un procedimiento simplificado de despacho aduanero en el comercio intrazona

\footnotetext{
${ }^{51}$ Decisión CMC № 22/02, por la que se reemplazó el Anexo de la Decisión 64/00.

52 Taccone, Juan José; Nogueira, Uziel (editores), Informe MERCOSUR, N ${ }^{\circ}$ 7, BID/INTAL, Buenos Aires, 2001. Las restricciones no se daban sólo entre los socios más grandes del bloque, sino que afectaba también a las economías de menor tamaño. El mismo año, un consultor de Paraguay identificaba las principales restricciones que sufría su país en el comercio con sus socios: con Argentina, señalaba regulaciones de etiquetado para las prendas de vestir y las de transporte; una suspensión total de comercio de pollos y espirales contra mosquitos y, en 2001, precios de referencia para determinados productos, entre los cuales se encontraban las vestimentas de algodón; con Brasil, registros de producto, registros de establecimiento del exportador, trámites aduaneros excesivos, exigencias de contenido regional y registros fitosanitarios; con Uruguay, se identificaba el mismo tipo de restricciones, sobresaliendo las regulaciones de etiquetado en prendas de vestir. Centurión López, Aldo, op. cit.

${ }^{53}$ Se trata de las resoluciones № 34/04 y 21/05. Cabe destacar el mecanismo que esta última resolución establecía para facilitar el abordaje de conflictos por restricciones no arancelarias "caso por caso". De manera resumida, dadas ciertas condiciones, cualquier estado parte afectado podría remitir una solicitud por escrito a la Presidencia pro tempore, con copia a los coordinadores nacionales de la CCM solicitando la adopción de acciones que destrabasen el conflicto. El estado al que se le solicitaba esto tendría 10 días para expedirse. Luego los coordinadores nacionales de la CCM se expedirían sobre la cuestión y realizarían "sus mejores esfuerzos para solucionar el problema". La Presidencia pro tempore se comunicaría con dichos coordinadores y "la decisión" sería "notificada a los Coordinadores Nacionales de los Estados Partes a través de la Presidencia pro tempore". Si se analiza el texto original, se observa que es vago respecto de quién toma la decisión y cuál es la obligatoriedad de la misma. Ese mismo año comenzaba a negociarse el Mecanismo de Adaptación Competitiva, luego de que el entonces Ministro Roberto Lavagna dirigió a las autoridades brasileñas una propuesta basada en tres tipos de instrumentos: (i) un mecanismo transitorio de salvaguardias ante situaciones de fuerte asimetría macroeconómica; (ii) un mecanismo de salvaguardias sectorial denominado "Cláusula de Adaptación Competitiva"; y (iii) un "Código de buenas prácticas de empresas". Las negociaciones desarrolladas a partir de entonces tuvieron carácter casi exclusivamente bilateral y se concentraron en el segundo instrumento, que terminaría constituyendo el Mecanismo de Adaptación Competitiva. Informe MERCOSUR, N¹1, BID/INTAL, Buenos Aires, enero 2007, pág. 57.
} 
que, en líneas generales, se limitaba a dar prioridad a operadores regulares de este comercio en los procesos de verificación y despacho ${ }^{54}$.

En 2005, el primer pronunciamiento del Tribunal Permanente de Revisión del MERCOSUR, surgido a raíz de un conflicto comercial por neumáticos remoldeados entre Argentina y Uruguay, obligó a Argentina a derogar o modificar la ley que prohibía dichas importaciones. En línea con la construcción de realidades a partir de interpretaciones de ciertos actores referida en la sección 2, es interesante señalar que el laudo interpretaba que en el MERCOSUR existía "un solo principio (el libre comercio), al cual se le pueden anteponer ciertas excepciones". Citando jurisprudencia de la Comunidad Europea como referencia, este fallo establecía los "criterios de rigor" para la invocación de excepciones al principio de libre comercio, es decir, los criterios según los cuales el tribunal debía interpretar si permitir o prohibir la restricción en cuestión:

- la efectiva afectación del comercio recíproco; el carácter discriminatorio de la medida (si se aplicaba a productos nacionales y extranjeros y/o si afectaba de manera distinta a cada uno);

- $\quad$ su justificación (que podría obtenerse en relación al medio ambiente o la seguridad, por ejemplo, pero no como protección de un sector industrial); y

- $\quad$ su proporcionalidad (respecto al objeto que se quiere proteger, por ejemplo, el medio ambiente. Este criterio estaba estrictamente vinculado al anterior, la justificación) ${ }^{55}$.

Argentina presentó un recurso de aclaratoria, al que siguió el laudo № 1/2006 del Tribunal Permanente de Revisión. Transcurrido el plazo que había fijado el Tribunal para el cumplimiento del laudo y sin que Argentina dictara norma alguna para dar cumplimiento al mismo, el poder ejecutivo de Uruguay emitió el decreto $N^{\circ}$ 142/07 imponiendo medidas compensatorias contra el país ${ }^{56}$ y mostrando la reducida capacidad de enforcement del Tribunal.

Al año siguiente, Argentina y Brasil acordaban el Mecanismo de Adaptación Competitiva (MAC), que establecía una serie de pasos formales consensuados para restringir importaciones en ciertos sectores si alguno de los dos países se veía perjudicado por las importaciones de su vecino. Se trató de un acuerdo alcanzado de manera bilateral, cuyas negociaciones implicaron casi 15 meses de propuestas y contrapropuestas ${ }^{57}$, y que tomó la forma de un Protocolo Adicional al Acuerdo de Complementación Económica № 14, aquél que había dado origen al MERCOSUR. El acuerdo fue alcanzado luego de un año y medio de negociaciones y bajo la férrea oposición de la entidad cúpula paulista FIESP, pese a la cual el gobierno brasileño accedió $^{58}$.

\footnotetext{
${ }^{54}$ Resolución GMC № 2/09.

55 Laudo no 1/2005, C.3: Criterios de rigor para el análisis de la viabilidad de las excepciones al libre comercio, disponible en: http://www.sice.oas.org/dispute/mercosur/Laudo001 005 s.pdf. [consulta: 08 de agosto de 2015].

${ }^{56}$ Britti, María Soledad, La opción de Foro en el Sistema de Solución de Controversias del MERCOSUR, Edición electrónica gratuita, 2009, disponible en: www.eumed.net/libros/2009a/516/.

57 Informe MERCOSUR, N¹1, pág. 57.

58 "Esto es un grave error", Diario Página 12, 2 de febrero de 2006 y entrevista a Federico Meira (FIESP). El brasileño indicó que el acuerdo sobre el MAC fue cerrado por el gobierno brasileño, especialmente su Ministerio de Industria y su Cancillería, con una posición "ideológica" y "sólo para satisfacer al gobierno
} 
Para la aplicación del MAC, se debían cumplir ciertos requisitos. Entre ellos, que los solicitantes reunieran un grupo de productores que representara al menos un $35 \%$ de la producción nacional y que el aumento de las importaciones produjese un "daño importante" 0 una amenaza de dicho daño (cuya definición incluía: caída en las ventas del producto nacional, en el nivel de producción y empleo y en el uso de la capacidad instalada, entre otros). Luego de que la solicitud fuese analizada por el perjudicado ("importador"), el mecanismo comenzaría con un período de consultas (30 días prorrogables por 60 más) entre sectores privados afectados, para estudiar la posibilidad de acuerdos sobre integración productiva, cuotas de importación, u otras medidas. En caso de no haber acuerdo entre ellos, el importador (luego de un procedimiento de investigación y comprobación del daño) debía notificar a la Comisión de Monitoreo del Comercio Bilateral y "solicitarle que invite a la rama de producción nacional, a los exportadores y a la AN [Autoridad Nacional] del Estado Exportador a mantener consultas" por un plazo de 10 días, prorrogables por otros 10. Cuando no se lograse acuerdo en los pasos previos, se permitiría al importador adoptar el MAC, que consistiría en:

- un contingente arancelario anual con preferencia plena para las exportaciones del producto considerado del otro ;

- un arancel para las exportaciones del producto del otro que supere el nivel del contingente arancelario anual que sea igual al Arancel Externo Común con una preferencia del $10 \%$.

Según el Protocolo, el MAC se podría aplicar por 3 años (prorrogable por un año más) y una vez que perdiese su vigencia no podía volver a aplicarse antes de que se cumplieran dos años de esa fecha ${ }^{59}$. Ni bien se conoció el acuerdo, comenzaron los rumores de utilización de dicho mecanismo por parte de sectores de ambos países ${ }^{60}$, cosa que nunca sucedió, ya que este mecanismo no entró en vigencia (hasta la fecha de este artículo).

En 2007, a propuesta de Uruguay, se aprobó la decisión CMC № 27/07, según la cual se instruía al GMC a definir el tratamiento para las restricciones y medidas no arancelarias antes del 31 de diciembre de 2008. El plazo máximo de la implementación de las soluciones acordadas sería diciembre de 2010 para medidas aplicadas por Argentina y Brasil y la misma fecha de 2012 para Paraguay y Uruguay. Una vez más, el primer paso era la identificación de las restricciones, tarea que se había iniciado desde los primeros años del proceso pero que, evidentemente, requería continua actualización por los cambios en las medidas comerciales de los países. Así, cada parte presentó sus respectivos listados en la LXX reunión ordinaria del

argentino", sin contactos con el sector privado de Brasil, que se oponía rotundamente al mismo. Solo más tarde participaría el sector privado en la definición de los detalles del mecanismo, momento en el que habrían logrado que el acuerdo fuese "inaplicable", una definición cercana a la apreciación que el personal de CIC tuvo sobre el mecanismo, como se aprecia al final del párrafo. Algunos analistas y funcionarios de ambos países destacaron, sin embargo, la ganancia en términos de previsibilidad y transparencia que resultaría de la instauración del MAC, al que incluso consideraron una garantía jurídica para los inversores extranjeros. Informe MERCOSUR, $\mathrm{N}^{\circ} 11$, pág. 63.

${ }^{59}$ Protocolo Adicional al ACE 14: "Adaptación competitiva, integración productiva y expansión equilibrada y dinámica del comercio", 1/2/2006. El acuerdo se protocolizó en la ALADI en abril de 2006. Para una explicación detallada y gráfica del mecanismo, ver lbidem, pág. 61-62.

${ }_{60}$ Ver, por ejemplo, "Brasil alerta que podría restringir el ingreso de productos argentinos", El Cronista, 7 de febrero de 2006 y "Empresarios de Argentina y Brasil buscan hacer las paces", Clarín, 13 de febrero de 2006. 
GMC (10 y 11 de diciembre de 2007) ${ }^{61}$. Desde ese momento, no se registraron avances respecto de esas medidas. Según el INTAL, las significativas tasas de crecimiento económico de los socios, la expansión de las inversiones de Brasil en la región y la apreciación del real se combinaron para favorecer el crecimiento del comercio regional sin grandes conflictos ${ }^{62}$. También la sintonía política que hubo entre los líderes de Argentina y Brasil (que, como se verá más adelante, ponía el foco en otros aspectos de la integración que no fueran estrictamente aquellos comerciales) contribuyó a que los gobiernos se esmeraran en mantener bajo el nivel de los conflictos comerciales. Así, las restricciones existentes se naturalizaban gradualmente como parte necesaria del proceso. Claro que esta situación no fue duradera: cuando los países de la región intentaron amortiguar los efectos de la crisis económica y financiera internacional restringiendo importaciones, reaparecieron los conflictos sectoriales intensos. Para 2009, momento en el que concluye el período de este estudio, el aumento de la cantidad de licencias no automáticas impuestas por Argentina, cuyos principales blancos fueron las importaciones de Brasil y China, hicieron que su socio principal del MERCOSUR reaccionara con similares medidas nacionales para frenar importaciones de productos argentinos. En cambio, como se observa en la tabla 2, el uso de estas licencias no redundó en nuevos casos de controversias ante los tribunales del MERCOSUR.

Tabla 2. Controversias con laudo arbitral $1999-2008^{63}$

\begin{tabular}{|l|l|l|l|l|}
\hline Controversia & $\begin{array}{l}\text { País que } \\
\text { representa }\end{array}$ & $\begin{array}{l}\text { País cuyas } \\
\text { medidas son } \\
\text { recurridas }\end{array}$ & Fecha & Laudo \\
\hline Tribunal Arbitral Ad hoc (Protocolo de Brasilia) \\
\hline $\begin{array}{l}\text { 1.- Comunicados DECEX. Licencias } \\
\text { automáticas y no automáticas de } \\
\text { Brasil a la importación }\end{array}$ & Argentina & Brasil & $28 / 04 / 99$ & $\begin{array}{l}\text { Favorable } \\
\text { a } \\
\text { Argentina }\end{array}$ \\
\hline $\begin{array}{l}\text { 2.- Carne de cerdo. Subsidios a la } \\
\text { producción y exportación de cerdos } \\
\text { del Brasil }\end{array}$ & Argentina & Brasil & $27 / 09 / 99$ & $\begin{array}{l}\text { Favorable } \\
\text { a } \\
\text { Brasil }\end{array}$ \\
\hline $\begin{array}{l}\text { 3.- Productos Textiles. } \\
\text { Salvaguardias aplicadas por } \\
\text { Argentina }\end{array}$ & Brasil & Argentina & $10 / 03 / 00$ & $\begin{array}{l}\text { Favorable } \\
\text { a } \\
\text { Brasil }\end{array}$ \\
\hline $\begin{array}{l}\text { 4.- Pollos. Derechos antidumping } \\
\text { contra pollos provenientes de Brasil }\end{array}$ & Brasil & Argentina & $21 / 05 / 01$ & $\begin{array}{l}\text { Favorable } \\
\text { a Argentina }\end{array}$ \\
\hline $\begin{array}{l}\text { 5.- Bicicletas. Restricciones de } \\
\text { acceso de bicicletas de origen } \\
\text { uruguayo al mercado argentino }\end{array}$ & Uruguay & Argentina & $29 / 09 / 01$ & $\begin{array}{l}\text { Favorable } \\
\text { a Uruguay }\end{array}$ \\
\hline $\begin{array}{l}\text { 6.- Neumáticos. Prohibición de } \\
\text { importación de neumáticos } \\
\text { remoldeados del Brasil procedentes } \\
\text { de Uruguay }\end{array}$ & Uruguay & Brasil & $09 / 01 / 02$ & Favorable \\
\hline $\begin{array}{l}\text { 7.- Fitosanitarios. Obstáculos al } \\
\text { ingreso de productos fitosanitarios } \\
\text { argentinos al mercado de Brasil por } \\
\text { incumplimiento Resoluciones GMC }\end{array}$ & Argentina & Brasil & $19 / 04 / 02$ & Favorable \\
\hline
\end{tabular}

\footnotetext{
${ }^{61}$ Acta GMC № 04/07.

62 Informe MERCOSUR, N¹3, BID/INTAL, Buenos Aires, febrero 2009, pág. 111.

${ }^{63}$ Cabe señalar que fuera del período de estudio y hasta la fecha de elaboración de este artículo, sólo se sumaría a esta tabla un laudo, en el año 2012, en relación con la suspensión de la participación de Paraguay en los órganos del MERCOSUR y la incorporación de Venezuela como miembro pleno.
} 


\begin{tabular}{|l|l|l|l|l|}
\hline $\begin{array}{l}\text { 8.- IMESI. Impuesto Específico } \\
\text { interno a la importación de cigarrillos } \\
\text { del Paraguay al Uruguay }\end{array}$ & Paraguay & Uruguay & $21 / 05 / 02$ & $\begin{array}{l}\text { Favorable } \\
\text { a Paraguay }\end{array}$ \\
\hline $\begin{array}{l}\text { 9.- Estímulo a la industrialización de } \\
\text { lana }\end{array}$ & Argentina & Uruguay & $04 / 04 / 03$ & $\begin{array}{l}\text { Favorable } \\
\text { a Argentina }\end{array}$ \\
\hline $\begin{array}{l}\text { 10.- Medidas discriminatorias y } \\
\text { restrictivas al comercio de tabaco y } \\
\text { productos derivados del tabaco }\end{array}$ & Uruguay & Brasil & $05 / 08 / 05$ & $\begin{array}{l}\text { Favorable } \\
\text { a } \\
\text { Uruguag }\end{array}$ \\
\hline Tribunal de Revisión Permanente (Protocolo de Olivos) & & & \\
\hline $\begin{array}{l}\text { 1/2005.- Prohibición de importación } \\
\text { de neumáticos remoldeados de } \\
\text { Uruguay }\end{array}$ & Uruguay & Argentina & $20 / 12 / 05$ & $\begin{array}{l}\text { Favorable } \\
\text { a Uruguay }\end{array}$ \\
\hline $\begin{array}{l}\text { 2/2006.- Impedimentos a la Libre } \\
\text { Circulación derivado de los Cortes } \\
\text { en Territorio Argentino }\end{array}$ & Argentina & $\begin{array}{l}\text { Tribunal } \\
\text { Arbitral ad } \\
\text { hoc }\end{array}$ & $06 / 07 / 06$ & $\begin{array}{l}\text { Favorable } \\
\text { al Tribunal } \\
\text { Arbitral ad } \\
\text { hoc }\end{array}$ \\
\hline $\begin{array}{l}\text { 1/2007.- Exceso en la aplicación de } \\
\text { medidas compensatorias de } \\
\text { Uruguay }\end{array}$ & Argentina & Uruguay & $08 / 06 / 07$ & $\begin{array}{l}\text { Favorable } \\
\text { a Uruguay }\end{array}$ \\
\hline $\begin{array}{l}\text { 1/2008.- Divergencia sobre el } \\
\text { cumplimiento del laudo 1/2005 }\end{array}$ & Argentina & Uruguay & $25 / 04 / 08$ & $\begin{array}{l}\text { Favorable } \\
\text { a Uruguay }\end{array}$ \\
\hline
\end{tabular}

Fuente: Elaboración propia en base Centurión López, Aldo, op. cit. y a la sección "Solución de ontroversias" de la página web del MERCOSUR, disponible en: http://www.mercosur.int/innovaportal/v/375/2/innova.front/laudos[consulta: 08 de agosto de 2015].

En este breve recorrido se ve que no fueron pocas las decisiones regionales referidas a RNA que formaron parte de la normativa del MERCOSUR. El tema fue previsto desde el primer tratado que dio origen a este proceso de integración. Luego, la creación de la CCM en 1994 junto a la liberación del comercio intrazona de la mayoría de los productos el mismo año (y de casi todos en 1999) generó más normas que abordaban el tema. Finalmente, los laudos de los tribunales se concentraron en controversias originadas por el mismo. Sin embargo, el último laudo del Tribunal fue emitido en 2008, mientras que una larga serie de conflictos originados en restricciones no arancelarias era tratada, durante todo el período de estudio, a través de negociaciones bilaterales entre los países. Esto hizo que en 2010 Uruguay presentara una propuesta para elaborar un mecanismo de reclamo directo ante el Tribunal en el caso de medidas no arancelarias que afectaran el comercio intrazona. Su principal argumento era que, bajo los mecanismos de consultas a la CCM y presentaciones al Tribunal, se producía una dilación en la solución de los problemas de acceso al mercado. La propuesta fue bien recibida por Paraguay, pero no por Argentina y Brasil. Se aprobó, a cambio, la decisión № 56/10 con un "Programa de Consolidación de la Unión Aduanera" que, entre otras cosas, instruyó a la CCM a:

- constituir un grupo de trabajo sobre medidas no arancelarias $^{66}$ con el objetivo de

\footnotetext{
${ }^{64}$ Aunque en términos formales la controversia se da por terminada porque Brasil adapta su normativa según la demanda de Uruguay antes de que el Tribunal emita su laudo.

65 Este caso tuvo especial repercusión política, debido a que los cortes (que duraron años) fueron provocados por la oposición a la instalación de una papelera en territorio uruguayo pero sobre el río Uruguay (limítrofe entre ambos países). Uruguay primero recurrió a un Tribunal Ad Hoc para presentar su demanda contra Argentina, el fallo le fue favorable, y a consecuencia Argentina presentó este recurso ante el Tribunal de Revisión Permanente. Se señala este laudo y no el 1/2006, que es un laudo complementario con una aclaración sobre el laudo del año anterior, 1/2005.

${ }^{66}$ Cabe recordar que el Comité Técnico № 8 sobre "Restricciones y Medidas No Arancelarias" se había eliminado en año 2000 (Decisión CMC №59/00).
} 
establecer procedimientos de intercambio de información para que los s partes comunicaran la introducción o modificación de exigencias para la entrada de mercaderías importadas a su territorio;

- revisar el sistema de consultas establecido en la directiva № 17/99 (ver arriba) para agilizar el tratamiento de las medidas no arancelarias mencionadas en el artículo anterior;

- elevar al GMC una propuesta del tratamiento de las medidas no arancelarias para asegurar la libre circulación en el comercio intrazona ${ }^{67}$.

Sin embargo, los años siguientes no se registraron nuevas decisiones vinculadas a estos objetivos, al punto que el INTAL señalaba en 2013 que el programa estaba "prácticamente congelado"68.

De esta manera, la inclusión temprana del tema en la normativa del MERCOSUR parecía expresar la idea de que eran un instrumento ilegítimo en el proceso de integración; sin embargo, fueron limitados tanto la identificación de las RNA como el establecimiento de mecanismos regionales que resultaran eficaces para los socios que las denunciaran. El resumen concentrado en las RNA argentinas que se realiza a continuación mostrará que, como consecuencia, un sinnúmero de aquellos conflictos terminaron abordados a nivel político y de manera bilateral.

\section{UN RECORRIDO POR LAS RESTRICCIONES NO ARANCELARIAS ARGENTINAS EN EL MERCOSUR (1999-2008)}

Son varios los autores que, analizando la evolución del MERCOSUR, consideran 1998 como último año en el que existió una clara "perspectiva optimista" respecto de la consolidación del proceso de integración; a partir de entonces, se inicia una nueva etapa más conflictiva del proceso, de manera coincidente con la crisis externa brasileña (que terminó en la devaluación de su moneda en $1999^{69}$ y fue seguida de un período de severa recesión en la región), con un continuado retroceso del intercambio comercial intrazona (ver gráfico 1), y con la crisis argentina de $2001^{70}$. Así, mientras se acercaba la conclusión del proceso de desgravación arancelaria (los últimos ítems del Régimen de adecuación iban llegando a arancel cero), los países del MERCOSUR tendieron a fortalecer la protección por vías no arancelarias de sus

\footnotetext{
${ }^{67}$ Decisión CMC № 56/10.

${ }^{68}$ Informe MERCOSUR, N ${ }^{\circ} 18$, BID/Intal, Buenos Aires, 2013, pág. 85.

${ }^{69}$ Taccone, Juan José; Nogueira, Uziel (editores), op. cit. , pág. 12.

${ }^{70}$ Entre esos autores, ver, por ejemplo, Bouzas, Roberto, "EI MERCOSUR diez años después. ¿Proceso de aprendizaje o déjàvu?" (que separa lo que llama "la era de los mercados" entre 1995 y 1998 de la posterior "competencia conflictiva"); García de la Cruz, José Manuel (dir.); Lucena, Javier; Sánchez, Ángeles; Gayo, Daniel, La integración productiva en MERCOSUR: Orientaciones para la Unión Europea, Serie Avances de Investigación 41, Fundación Carolina CeALCI, Madrid, 2010, que divide la primera etapa de "consolidación del proceso y expansión comercial" entre 1991 y 1998 de la posterior etapa de "crisis económica e institucional" entre 1999 y 2002, para luego destacar la tercera etapa hasta la actualidad, de "replanteamiento"; y Taccone, Juan José y Nogueira, Uziel (editores), op. cit., que señala desde 1999 un "impasse en el MERCOSUR" y considera por entonces que el trienio 1999-2001 quedará registrado como una de las peores etapas en la historia del MERCOSUR.
} 
sectores sensibles, frenando el impulso liberalizador de los inicios del proceso ${ }^{71}$.

Gráfico 1. Participación del comercio intrazona en las importaciones y exportaciones del MERCOSUR (en \%)

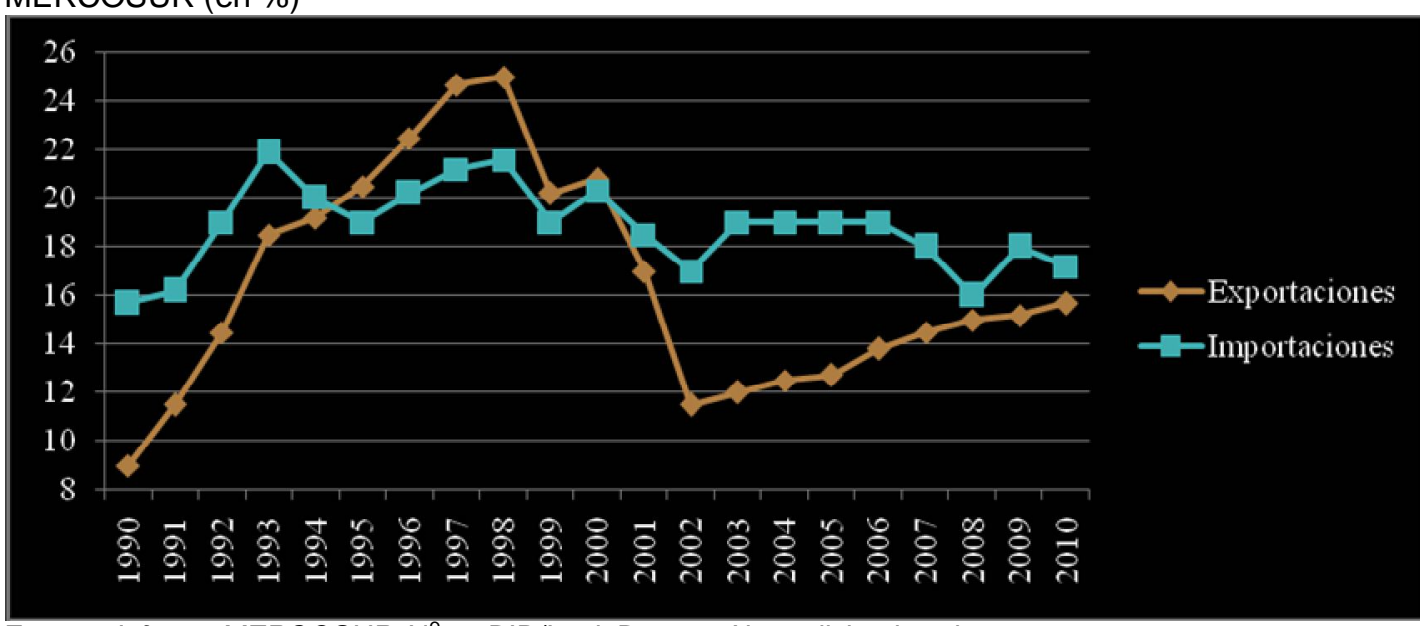

Fuente: Informe MERCOSUR, №16, BID/Intal, Buenos Aires, diciembre de 2011.

Aquella tendencia podía explicarse a partir de elementos del contexto regional e internacional que convergían. En primer lugar, en el campo monetario, la significativa devaluación del real de enero de 1999 provocó bruscas alteraciones de las paridades cambiarias bilaterales entre los países miembros, y tuvo un significativo impacto en la magnitud y dirección de los flujos comerciales intrazona. En segundo lugar, a fines de 2001, la ruptura del régimen de convertibilidad en Argentina agudizó la severa crisis económica y social del país, con consecuencias para toda la subregión ${ }^{72}$. Y en tercer lugar, se observó un deterioro del contexto internacional en varios ámbitos: la caída de la actividad económica en la mayoría de los países latinoamericanos; el enfriamiento del comercio internacional; y una fuerte caída en los precios internacionales de numerosos productos que formaban el grueso de las exportaciones de numerosas empresas del MERCOSUR. Esto llevó a una pérdida de rentabilidad y a la caída de las ventas de las empresas que operaban en la región ${ }^{73}$.

La situación se combinaba con el mencionado fin del Régimen de adecuación a la unión aduanera que implicó la eliminación, desde comienzos de 1999 en Argentina y Brasil, de los aranceles residuales existentes en los sectores "sensibles" del comercio, con lo que estos sectores quedaban expuestos a la competencia, justo en ese momento de deterioro del contexto internacional.

En este marco se multiplicó el número de conflictos y de choque de intereses comerciales entre los países del MERCOSUR, como consecuencia de la fuerte presión de numerosos sectores productivos a los gobiernos nacionales. Éstos, por un lado, articularon una amplia gama de argumentos y estrategias para defender a sus productores nacionales "sensibles" del uso de

\footnotetext{
${ }^{71}$ García de la Cruz, José Manuel (dir.) y otros, op. cit.

${ }^{72}$ En diciembre de 2001 estalló una crisis económica, política y social en Argentina, que incluyó protestas y saqueos masivos que llevaron a la renuncia de Fernando De la Rúa. Pasaron tres Presidentes interinos en 10 días hasta que se designó a Eduardo Duhalde como Presidente provisional. La dimensión económica estuvo marcada por el fin de la convertibilidad y la subsiguiente devaluación de la moneda argentina.

${ }^{73}$ García de la Cruz, José Manuel (dir.) y otros, op. cit.
} 
restricciones no arancelarias por parte de otros países ${ }^{74}$; por el otro, recurrieron a las mismas barreras frente a importaciones que los amenazaban.

Ya en 1998 se iniciaba el conflicto comercial que terminaría con la emisión, en 1999, del primer laudo del Tribunal Arbitral ad hoc del MERCOSUR. Los productos argentinos tenían dificultades para entrar en Brasil, ya que los trámites que antes duraban entre 24 y 48 horas, pasaron a tener un plazo incierto (consecuencia de la ampliación de las exigencias de control a las importaciones adoptadas por el gobierno brasileño). Productos agropecuarios, farmacéuticos, químicos y alimenticios habían quedado sometidos a la presentación de licencias previas de importación antes y después de la entrada de la mercadería en el país. Argentina había presentado ya un reclamo contra el uso de ese mecanismo en 1998; había pedido que Brasil excluyese al MERCOSUR de la norma que exigía licencia previa en las ventas al mercado y hasta que se crease un "canal verde" de forma tal que los miembros del bloque pudiesen dinamizar el pasaje de productos por las fronteras, evitando así perjuicios a sus exportaciones. Ante la negativa brasileña ${ }^{75}$, se inició la disputa y el referido instrumento fue juzgado a través del Sistema de Solución de Controversias. Como se ve en la tabla 2, en abril de 1999 se conoció el laudo final sobre la cuestión, que obligó a Brasil a suspender el uso de ese mecanismo. No era el único país con RNA hacia sus vecinos (de hecho, pueden verse en el mismo cuadro otros casos que involucran a otros países aplicando dichas barreras) ${ }^{76}$, ni era el único tema que causaba conflictos comerciales. Pero es sugerente que el primer laudo se dedicase a ellas y que, ya en 2000 (y adelantando la importancia que tendría este tipo específico de RNA) el INTAL se preguntara si las licencias serían un "problema $\sin$ fin"”77.

Aun así, como se adelantó en la sección anterior, sólo algunos de los conflictos comerciales a raíz de RNA se traducían en controversias legales ante los tribunales arbitrales del MERCOSUR. El resto se resolvía a través de la presentación de reclamaciones y consultas ante la $\mathrm{CCM}^{78}$ o bien al máximo nivel político. Tal fue el caso de la controversia causada por la resolución argentina № 911/99, que invocaba una norma de la ALADI para aplicar medidas de

\footnotetext{
${ }^{74}$ Ibidem y Taccone, Juan José; Nogueira, Uziel (editores), op. cit.

${ }^{75}$ A partir de noviembre de 1998, Brasil también adoptó, a través de la reglamentación del Instituto Nacional de Metrología (Inmetro), mecanismos para exigir la certificación de calidad para las importaciones de cerca de 170 ítems industrializados (entre ellos, aparatos electrónicos, vidrios de seguridad, electrodomésticos).

${ }^{76}$ Por su lado, Argentina adoptó nuevos mecanismos de control de sus importaciones a partir de marzo de 1999. El sistema de solicitudes de destino de importación para consumo obligaría a los importadores argentinos a llenar un formulario informativo indicando cantidades y valores FOB de lo que pretendían importar para todas las importaciones por arriba de US\$ 80 mil (resolución 150/99 y 11/99 de la Secretaría de Industria, Comercio y Minería), pero la autorización sería automática. A eso se sumaba que a partir de junio los importadores argentinos también debían hacer una declaración detallada de todas las mercaderías importadas e internadas en depósitos fiscales en el Sistema Informático María (resolución № 565/99, sancionada por la Administración Federal de Ingresos Públicos, AFIP), similar al Siscomex brasileño. Finalmente, desde julio del mismo año, una reglamentación del Servicio Nacional de Sanidad y Calidad Agroalimentaria (SENASA) prohibió la entrada en el país de productos de origen animal y vegetal in natura sin certificación sanitaria. La reglamentación afectaba especialmente al comercio fronterizo. Informe MERCOSUR, N 5 , BID/INTAL, Buenos Aires, 1999, pág. 24.

77 Informe MERCOSUR, Nº, BID/INTAL, Buenos Aires, 2000.

${ }^{78}$ Entre 1999 y 2002, las consultas estuvieron prácticamente monopolizadas por Argentina, que interpuso casi un $60 \%$ del total. El país que recibió más consultas fue Brasil (más de la mitad). García de la Cruz, José Manuel (dir.) y otros, op. cit., pág. 25. Todos los Informes MERCOSUR publicados por BID/INTAL citados en la bibliografía de esta investigación proveen buenas síntesis de los casos de mayor repercusión en todo el período de estudio.
} 
salvaguardia $^{79}$. El gobierno brasileño reaccionó enérgicamente: por vez primera desde la creación del bloque, anunció a través del vicesecretario de comercio exterior, José Alfredo Graça Lima, que todas las negociaciones quedaban suspendidas ${ }^{80}$. Eso hizo que el gobierno diera marcha atrás en su decisión ${ }^{81}$.

A cambio de recurrir a los tribunales, los gobiernos de Argentina y Brasil promovieron acuerdos entre privados de algunos sectores sensibles, que no dieron frutos. Finalmente el gobierno del primero anunció normas de etiquetado y registro para la importación de calzado y, semanas después, para ciertos tipos de papel envasado, que funcionaron como RNA ${ }^{82}$. A modo de ejemplo, el etiquetado para el calzado se dio a través de una reglamentación técnica ${ }^{83}$, que disponía que todo calzado comercializado en el país poseyera una etiqueta con información acerca de los materiales de elaboración junto a los datos del fabricante o importador. Pocos días más tarde, otra resolución introducía un sistema de licencias no automáticas de importación a los fines de certificar el cumplimiento del requisito de etiquetado ${ }^{84}$. Al reglamentarse las medidas anteriores, se estableció un plazo de más de tres meses para resolver la aprobación de las licencias ${ }^{85}$, disposición que en los hechos implicaba la virtual paralización de las importaciones intrazona hasta fines de 1999.

La respuesta de Brasil se dio en septiembre, con la restauración de los requisitos de licencias previas para la importación a unos 400 productos argentinos (principalmente, en productos químicos, automotores y alimentos) que habían sido eliminadas a principios de año. La tensión sólo pudo disiparse cuando, luego de intensas negociaciones oficiales y privadas, se alcanzaron acuerdos de restricción voluntaria de exportaciones entre las cámaras empresariales de ambos países en los sectores del calzado y el papel. De esa manera, Brasil suspendió las mencionadas licencias no automáticas ${ }^{86}$.

Durante el año 2000 hubo una serie de enfrentamientos por casos puntuales de restricciones no arancelarias aplicadas al ingreso de pollos, calzado, textiles y productos siderúrgicos a Argentina o de carne de cerdo, ajos, miel, lácteos a Brasil. Sin embargo, para fines de ese año

\footnotetext{
${ }^{79}$ Se refería a la resolución ALADI № 70/87 y básicamente a la posibilidad de imponer salvaguardias y restricciones a la importación de productos textiles, calzado, productos eléctricos y electrónicos, carne de pollo y productos del sector azucarero. En materia textil, en julio de 1999, el gobierno argentino decidió imponer cuotas de importación a cinco productos textiles brasileños como medida de salvaguardia, aplicada también a otros países exportadores (China y Paquistán), que duraría tres años. Los empresarios del sector en Argentina habían denunciado que las empresas brasileñas contaban con créditos subsidiados del BNDES y otras ventajas (como la devolución del PIS, créditos del FINAME y financiamiento a las exportaciones con interés preferencial). Las autoridades argentinas buscaron amparo para la aplicación de salvaguardia en el artículo sexto del Acuerdo de Vestimenta y Textiles de la OMC, alegando que las exportaciones causaban daño a su industria. El Órgano de supervisión de los Textiles, (OST) dictaminó que en lo concerniente a los dos primeros países, la medida no se encontraba justificada y, luego de reclamos brasileños, también ante la CCM, Argentina derogó la medida. Informe MERCOSUR, $\mathrm{N}^{\circ} 5$, pág. 28-29 y Ablin, Eduardo; Lucángeli, Jorge, "La política comercial argentina: Evolución reciente y limitaciones de los instrumentos futuros", Boletín Informativo Techint, octubre de 2000.

${ }^{80}$ Malamud, Andrés, "La diplomacia presidencial y los pilares institucionales del MERCOSUR: un examen empírico", Relaciones Internacionales, № 15, octubre de 2010.

81 Bermúdez, Ismael, "La diplomacia de presidentes evitó la guerra comercial con el Brasil", Clarín, 01/08/1999.

${ }^{82}$ Resoluciones de la Secretaría de Industria, Comercio y Minería 508/99 (publicada el 09/08/1999 en el Boletín oficial); 617/99 (publicada el 31/08/1999 en el Boletín oficial) y 653/99 (publicada el 08/09/1999 en el Boletín oficial) y $977 / 99$ del Ministerio de Economía y Obras y Servicios Públicos (publicada el $11 / 08 / 1999)$.

${ }^{83}$ Resolución 508/99.

${ }^{84}$ Resolución 977/99.

85 Resolución 617/99.

${ }^{86}$ Informe MERCOSUR, N ${ }^{\circ} 6$
} 
se alcanzaron algunos acuerdos; el más importante estuvo vinculado a la política automotriz, pero hubo también otros que resolvían conflictos por el ingreso de productos agrícolas y alimenticios argentinos a Brasil ${ }^{87}$. En 2001, las restricciones argentinas a la importación desde sus socios seguían concentrándose en productos como calzados, lavarropas, cocinas, bicicletas, textiles, lácteos y electrónicos ${ }^{88}$. Luego de la crisis de ese fin de año y el fin de la convertibilidad, a medida que el año 2002 avanzaba y se complicaba la situación económica de Argentina, seguía cayendo el comercio intrabloque, algo que llevó a Argentina y Brasil a realizar una "limpieza de la mesa de negociaciones". Esta limpieza consistía en alcanzar una serie de compromisos para solucionar las restricciones al comercio bilateral e intrazona en general $^{89}$, y fue el eje de las negociaciones bilaterales y regionales en 2002, pero su principal fruto fue un acuerdo sobre la política automotriz del MERCOSUR y no así la eliminación de restricciones no arancelarias ${ }^{90}$.

A partir de mediados de 2002, Argentina empezó una clara recuperación económica luego de su profunda crisis. La tasa de crecimiento de su PBI real en 2003 fue de $8,4 \%$, mientras que la de los demás países fue negativa ${ }^{91}$. Sin embargo, durante los años siguientes, los cuatro socios experimentaron una notoria mejoría de la actividad económica, mantuvieron tipos de cambio competitivos, superávits en la balanza comercial y mejora en los indicadores laborales ${ }^{92}$. La atracción de inversión extranjera directa también creció en la región ${ }^{93}$ y se verificó en el comercio exterior del bloque una tendencia constante de crecimiento, acompañado de un incremento en la participación del comercio intrarregional respecto del total, aunque sin llegar a los niveles de los años '90 (ver gráfico 1$)^{94}$.

Pese a esta recuperación y a un contexto internacional favorable, que parecía devolver al proceso cierto optimismo, se identificaron dos tendencias en este período que influirían en la política comercial argentina. En primer lugar, la dirección de los flujos de comercio intrazona mostraba que hacia fines de la década de 2000 Argentina era el país que más importaba desde sus socios, siendo el segundo que exportaba, teniendo por eso una clara tendencia al saldo comercial negativo con sus socios y, en especial, con Brasil (ver gráfico 2).

\footnotetext{
${ }^{87}$ Ibidem

${ }^{88}$ Entre otros, a las importaciones de estos productos se les fijaron precios mínimos de referencia y Brasil los evaluaba como muy altos, constituyendo entonces un obstáculo a la importación. Taccone, Juan José; Nogueira, Uziel (editores), op. cit. Además, Argentina era señalada por ser el usuario más activo de instrumentos de defensa comercial entre los países del MERCOSUR, siendo Brasil y China los orígenes más investigados por medio de esos instrumentos. Para conocer el listado de investigaciones por dumping y subsidios realizadas por la Argentina contra Brasil, Uruguay y Paraguay entre 1992 y 2003, ver Delgado, Ricardo, "Asimetrías y competencia: Aportes para un rediseño de los instrumentos comerciales," en Kosacoff, Bernardo (coord.), Evaluación del desempeño y aportes para un rediseño del MERCOSUR, CEPAL, Buenos Aires, 2004, pág. 92.

${ }^{89}$ Taccone, Juan José; Nogueira, Uziel (editores), Informe MERCOSUR, N ${ }^{\circ} 8, \mathrm{BID} / \mathrm{INTAL}$, Buenos Aires, 2003 , pág. 73 y 88.

90 lbid., pág. iii-iv.

${ }^{91}$ Las cifras fueron: Brasil $-0,2 \%$, Paraguay $-1 \%$ y Uruguay $-2,5 \%$. Juan José Taccone; Nogueira, Uziel (editores), Informe MERCOSUR, N 9, BID/INTAL, Buenos Aires, 2004.

92 Informe MERCOSUR, $\mathrm{N}^{\mathrm{O}} 10$.

93 Informe MERCOSUR, № 12, BID/INTAL, Buenos Aires, noviembre de 2007, pág. 28-38.

94 Cabe aclarar que en las exportaciones extrazona, las commodities tienen mayor peso que en las ventas intrazona. Mientras que en 2008 los precios de las materias primas presentaban niveles altos, en 1998 registraban su valor histórico más bajo. De ahí que la participación del comercio intrazona en el total esté subrepresentada, a pesar de su reciente y significativa expansión. Informe MERCOSUR, $\mathrm{N}^{\circ} 13$, pág. 32.
} 
Gráfico 2. Exportaciones, importaciones y saldo comercial de Argentina con Brasil (en miles de dólares)

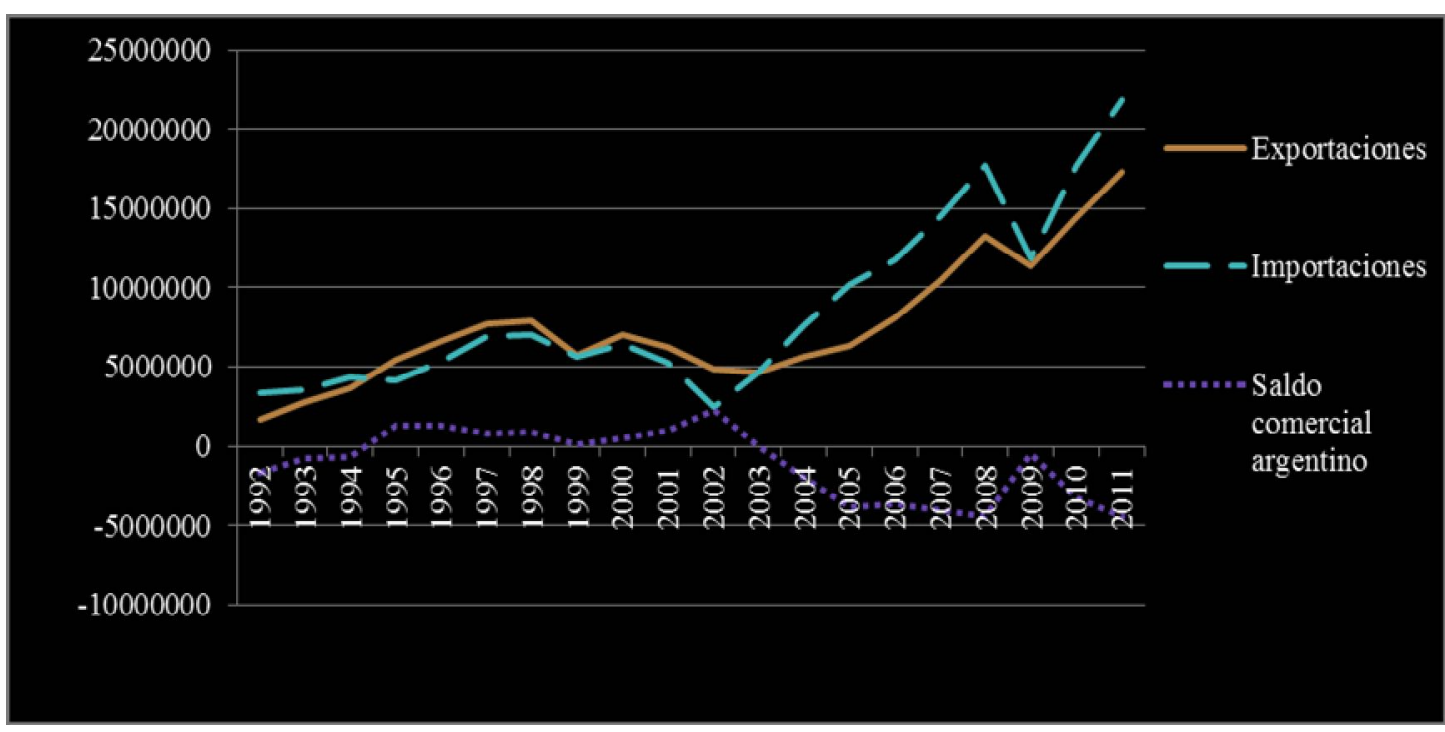

Fuente: Elaboración propia en base a datos de DATAINTAL, disponible en:

http://www10.iadb.org/dataintal/CnsConsultaCompleta.aspx [consulta: 6 de noviembre de 2013]

Brasil seguía siendo el principal origen de las importaciones argentinas, y estas importaciones crecían más rápido que las del resto del mundo. La tendencia se profundizó hasta 2008, cuando el superávit de Brasil con sus socios del MERCOSUR llegó a un 43\%. En particular, el déficit argentino para con su principal socio regional alcanzó el $63,5 \%$, equivalente a mil millones de dólares, igualando, en seis meses de ese año, un nivel superior al déficit registrado durante todo el año $2006^{95}$.

En segundo lugar, durante todo el período, sólo Brasil fue capaz de incrementar la importancia que el MERCOSUR tenía para su industria. Para los demás socios, la región perdía importancia como destino de sus exportaciones industriales. En el caso de Argentina, las exportaciones extrarregionales eran mayores que aquellas al MERCOSUR y, aunque del conjunto del bloque el principal destino del comercio seguía siendo Brasil, su importancia en el total de las importaciones brasileñas decaía ${ }^{96}$. Además, en 2008 se revertía la participación de su industria manufacturera en el mercado regional del $52 \%$ en 2002 al $37 \%{ }^{97}$.

Aquellas tendencias hicieron que esta segunda etapa, aún de pleno crecimiento económico, estuviera marcada por tensiones comerciales, en especial, entre Argentina y Brasil. Los conflictos sectoriales siguieron dominando las negociaciones regionales ${ }^{98}$ y los avances fueron tímidos, tanto en cuanto a las medidas proteccionistas intrazona, como en cuanto a la defensa comercial y a la consolidación del arancel externo común ${ }^{99}$. Desde 1999, todas las

\footnotetext{
95 Informe MERCOSUR, N ${ }^{\circ} 13$, pág. 34.

96 Informe MERCOSUR, $\mathrm{N}^{\circ} 11$, pág. 24-25. Un informe posterior del INTAL explicaba que la pérdida de participación de Argentina en las importaciones brasileñas se debía principalmente al desempeño de las ventas de dos productos: el petróleo y el trigo. Las ventas de ambos productos a Brasil cayeron significativamente entre 2002 y 2007. Informe MERCOSUR, N 13, pág. 60.

${ }^{97}$ García de la Cruz, José Manuel (dir.) y otros, op. cit., pág. 106.

98 Informe MERCOSUR, № 10, pág. 41.

99 Taccone, Juan José; Nogueira, Uziel (editores), Informe MERCOSUR, № 9, pág. 68. En cambio, se registraron avances en otras decisiones del GMC relativas al tratamiento de empresas públicas y metodología de cálculo del núcleo de inflación; a la liberalización del comercio de servicios (IV ronda de
} 
controversias atendidas por el Tribunal Arbitral $A d-h o c$ fueron controversias comerciales a causa de RNA; el panorama no cambió cuando el Protocolo de Olivos puso en funcionamiento el Tribunal de Revisión Permanente (2005), tal como se puede ver en la tabla 2. De todas maneras, durante todo el período hubo muchos más conflictos comerciales que los que se presentaron ante los tribunales, sólo que fueron canalizados y resueltos por otras vías.

En Argentina, la preocupación por el creciente déficit comercial con Brasil iría en aumento y daría bases al cuestionamiento sobre el tipo de vinculación económica que propiciaba el MERCOSUR, que ahora se veía como "desindustrializador" para Argentina ${ }^{100}$. El gobierno propugnaba por un "replanteo de fondo respecto del MERCOSUR"101. Se apuntaba a "equilibrar el marcado sesgo mercantilista que la formalización institucional de los años '90 [había impreso] a la estructura" del bloque ${ }^{102}$. Y se redoblaba la presión para frenar las importaciones brasileñas en varios sectores, tal como señalaba un funcionario, "según la coyuntura, aunque con la intención de largo plazo de reducir la participación de Brasil en el mercado local para fortalecer a la producción nacional”103. En la conferencia anual de la Unión Industrial Argentina de 2006, el entonces Secretario de Industria, Miguel Peirano ${ }^{104}$ admitía que se había abandonado "la apertura comercial como fin en sí mismo", y destacaba las decisiones del gobierno de restringir el comercio como medio para el desarrollo industrial del país, mostrando como ejemplo de éxito de tales decisiones la recuperación de sectores previamente "al borde de la extinción". El Secretario hacía explícito que el gobierno priorizaba "en cada una de sus decisiones el impacto" que ellas tenían "sobre la producción, sobre las inversiones y sobre el empleo", pero buscaba, a la vez, dar un lugar al proceso de integración sentenciando que "tenemos una enorme valorización del mercado interno que tiene la Argentina y que tiene el MERCOSUR"105.

Así, las medidas que adoptó Argentina en esta segunda etapa con vistas a restringir las importaciones desde el país vecino convivieron con el objetivo prioritario explícito del gobierno del "fortalecimiento del MERCOSUR". El gobierno consideraba que su principal desafío era "avanzar en su consolidación como un mercado único, dotado de una estructura institucional funcional a la búsqueda de integración productiva efectiva de las cadenas de valor regionales". El tema de la integración productiva dominaría la agenda regional en este período ${ }^{106}$. E concepto abarcaba distintas propuestas: desde la coordinación de políticas científicas y tecnológicas hasta la creación de cadenas productivas regionales, promoción de joint ventures entre PyMEs, financiamiento regional para el sector productivo e infraestructura regional, entre

negociaciones, 2003); y a la entrada en vigencia del Protocolo de Olivos para la solución de controversias (2004)

100 Paikin, Damián, "La Argentina y el MERCOSUR en tiempos de crisis internacional: las bases regionales del modelo kirchnerista", en Sarti, INgrid et al., Por uma integraçao da América do Sul no século XXI, Volume 1, Fomerco, Rlo de Janeiro, 2013, pág. 96.

${ }^{101}$ Kanenguiser, Martín, "Buscan frenar importaciones brasileñas", La Nación, 21 de abril de 2005.

102 Taiana, Jorge, "Objetivos y desafíos de la política exterior argentina", DEP Diplomacia, Estrategia, Política, junio de 2006, pág. 11.

${ }^{103}$ Kanenguiser, Martín, op. cit.

104 El Secretario había trabajado, entre 2003 y 2004, como asesor de la subsecretaria de Pequeña y Mediana Empresa y Desarrollo Regional, donde se ocupaba especialmente de la resolución de las asimetrías entre Argentina y Brasil. Entre julio y diciembre de 2007 fue Ministro de Economía y Producción.

105 " $12^{\mathrm{a}}$ Conferencia Industrial Argentina", Unión Industrial Argentina, Córdoba, 18, 19 y 20 de octubre, pág. 173-174.

${ }^{106}$ Taiana, Jorge, op. cit., pág. 13-14. 
$\operatorname{otros}^{107}$.

La elección del Presidente Luiz Inácio Lula da Silva en Brasil facilitó el diálogo por la preocupación argentina, pero las respuestas a ella se mantuvieron en la dimensión comercial, favoreciendo, por ejemplo, acuerdos de restricción voluntaria de importaciones o avalando informalmente las licencias no automáticas que Argentina imponía a ciertos sectores, y sin avanzar hacia planes estratégicos para integrar cadenas productivas o alcanzar una política industrial común ${ }^{108}$. La "evidente compatibilidad ideológica"109 entre Néstor Kirchner y Luiz Inácio Lula da Silva permitió que Brasil diera lugar a estos temas, prioritarios para Argentina más que para su vecino.

En este marco, las restricciones comerciales argentinas se transformarían en las principales herramientas de administración de comercio con las que el gobierno argentino buscaría orientar la sustitución de importaciones y dar forma al desarrollo industrial, evitando que se transformaran en un nuevo conflicto regional. Esta situación, sin embargo, no sería estable, ya que los reclamos contra las restricciones resurgirían a lo largo de todo el período ${ }^{110}$.

Entre los conflictos de más resonancia figuró el anuncio de Argentina, en vísperas de la cumbre de Puerto Iguazú, en julio de 2004, de que restringiría el ingreso de electrodomésticos provenientes de Brasil a través de licencias no automáticas ${ }^{111}$. Ese episodio era corolario de negociaciones anteriores a la cumbre, en las que el país había propuesto varios mecanismos de restricción comercial que se activarían bajo ciertas condiciones, permitiendo así que el país o países afectados pudiesen imponer restricciones comerciales ${ }^{112}$. Brasil había rechazado esta idea (concediendo sólo la creación de una Comisión de monitoreo del comercio en 2003, luego llamada "Reunión Bilateral Argentina-Brasil"113) por lo cual Argentina avanzó con su anuncio de licencias. Las medidas anunciadas no se implementaron inmediatamente, sino que se presentaron más como presiones para lograr acuerdos de restricción voluntaria entre los privados y en efecto, fueron luego aplicadas para productos en los que no se alcanzaron dichos acuerdos (como, por ejemplo, lavarropas) ${ }^{114}$.

La creación de la Comisión bilateral de monitoreo de comercio en 2003 permitió que se desarrollara una mecánica previa a la decisión de establecer restricciones al comercio: los gobiernos primero promovían acuerdos entre los sectores privados involucrados y, de no alcanzarse, recién allí adoptaban alguna forma de restricción. Así se lograron desde entonces

\footnotetext{
107 Ibidem, pág. 25.

108 Cortes, María Julieta; Creus, Nicolás, "Entre la necesidad y la desilusión: los dilemas de la política exterior argentina hacia Brasil (2005-2009)," en La política exterior de Cristina Fernández. Apreciaciones promediando su mandato, Cerir/UNR, Rosario, 2010, pág. 379.

${ }_{109}$ Vigevani, Tullo; Ramanzini Jr, Haroldo, op. cit., pág. 91.

${ }^{110}$ En 2004 se creó el Consejo Empresario del MERCOSUR, con el objetivo de promover el diálogo entre estos actores y con los gobiernos; pero desde sus primeras reuniones, según describe el INTAL, los representantes del sector privado no lograron patrones comunes para iniciar acuerdos que los satisficieran. Aun así, durante su segunda reunión se lanzó también el Foro Empresarial del MERCOSUR, que acompañaría con futuros encuentros las cumbres de Jefes de Estado. Informe MERCOSUR, $\mathrm{N}^{\circ} 10$, 46-47. Recién en 2012, la decisión CMC 62/12 estableció que se reuniría siempre en las cumbres y sería organizado por la presidencia pro tempore del bloque.

${ }_{111}^{11}$ Taccone, Juan José; Nogueira, Uziel (editores), Informe MERCOSUR, Nº 9, pág. 68 y 77.

112 Como se adelantó en la nota 53, estos mecanismos eran: el mecanismo transitorio de resguardo frente a situaciones de fuerte asimetría macroeconómica; la cláusula de adaptación competitiva (devenida en el mencionado MAC) y el código de buenas prácticas empresariales. Las conversaciones se extendieron hasta 2006, cuando se consensuó el Mecanismo de Adaptación Competitiva.

113 Informe MERCOSUR, N ${ }^{0} 13$, pág. 111.

114 Taccone, Juan José; Nogueira, Uziel (editores), Informe MERCOSUR, N 9, pág. 77.
} 
varios acuerdos privados bilaterales para restringir la cantidad de importaciones a Argentina de diferentes sectores durante los siguientes años: textil, televisores, ropa blanca, calzados y vinos, entre otros ${ }^{115}$. De todas maneras, y en varios casos a modo de control de cumplimiento de estos acuerdos, Argentina aplicó licencias no automáticas a varios sectores, entre ellos, bicicletas (2003); artículos para el hogar (2004); juguetes y calzado (2005); motocicletas (2006); pelotas, textiles y partes de calzado (2007); productos metalúrgicos, hilados y tejidos $(2008)^{116}$. También restringió el acceso de importaciones permitiendo que ingresaran sólo por determinadas aduanas los materiales textiles y sus manufacturas; el calzado, las polainas y los juguetes, juegos, artículos de recreación o deporte y sus accesorios ${ }^{117}$.

A la creación de la Comisión bilateral siguieron las arduas negociaciones para crear el mencionado Mecanismo de Adaptación Competitiva (MAC), impulsado por el Ministro de Economía argentino, Roberto Lavagna. La sintonía política a nivel presidencial favoreció que Brasil lo aceptase, como se mencionó en la sección 3, aún con la oposición de su sector privado. Según el Ministro Lavagna, la idea era que, una vez aprobado el MAC, se eliminasen aquellas licencias no automáticas, algo que nunca tuvo lugar ${ }^{118}$.

Poco tiempo pasó para que las tensiones comerciales resurgieran a la luz de la crisis económica y financiera internacional de 2008, que afectó el comercio exterior de todos los países del MERCOSUR y también, aunque en menor medida, el comercio intrarregional ${ }^{119}$. Los precios de algunas materias primas claves en las exportaciones del bloque (petróleo, cereales y semillas oleaginosas), que habían aumentado hacia 2007, en 2008 empezaron a debilitarse, a lo que se sumó el pánico bursátil de septiembre y octubre de ese año, que hizo que el flujo de capital ya no se dirigiese a los productos básicos, sino a los bonos del Tesoro de Estados Unidos, con repercusiones directas en los mercados cambiarios de la región y una abrupta salida de capitales de los países del MERCOSUR ${ }^{120}$.

Como se adelantó, el saldo comercial argentino con el MERCOSUR, y en especial con Brasil, cayó al punto más bajo de todo el período de estudio (ver gráfico 2). Una "orientación defensiva" de su política comercial (básicamente, restricción de importaciones) contribuyó, entre otras medidas anticíclicas, a limitar los efectos de la crisis para su mercado; pero a la vez aumentó los conflictos comerciales con sus socios, ya que los controles a las importaciones aplicadas involucraban a sus productos de igual manera que a los de terceros ${ }^{121}$. Para 2008, el cuadro de situación de las restricciones aplicadas por Argentina a Brasil se resumía de la siguiente manera: había productos con licencias no automáticas de importación (principalmente calzado, línea blanca y papel), otros sujetos a medidas antidumping (transformadores; vasos,

\footnotetext{
115 Informe MERCOSUR, N ${ }^{\circ} 11$, pág. 57. Ver también el Anexo II del mismo informe.

${ }^{116}$ Secretaría de Comercio Exterior, disponible en:

http://www.comercio.gob.ar/web/index.php?pag=373\&btn=161\#cip [consulta: 09 de agosto de 2015].

117 "La Aduana restringe el acceso de importados", La Nación, 13/08/2005.

${ }^{118}$ Entrevista a Roberto Lavagna. La misma idea de temporalidad de las medidas se veía en artículos de ese entonces, como "Comenzaron trabas a productos brasileños: inició con calzado", Ámbito Financiero, 14 de septiembre de 2005 y "No baja el país barreras al calzado importado de Brasil", Ámbito Financiero, 3 de noviembre de 2005.

119 Informe MERCOSUR, N 14, BID/INTAL, Buenos Aires, diciembre de 2009, pág. 77.

${ }^{120}$ Informe MERCOSUR, $\mathrm{N}^{\circ} 13$, pág. 6. En Argentina, antes (durante el primer semestre de 2008) hubo una salida de capital financiero equivalente al $2,9 \%$ del PBI, en un escenario de incertidumbre a raíz de un conflicto tributario entre el gobierno y el sector agropecuario. Ibidem, pág. 8.

${ }^{121}$ Informe MERCOSUR, $\mathrm{N}^{\circ} 15$, pág. 119.
} 
copas y jarros de vidrio; y hojas de sierra manual); otros con salvaguardias (TV color) ${ }^{122}$. Hacia fines de ese año Argentina aumentó el uso de mecanismos de administración del comercio, tanto con el mundo como con el MERCOSUR. Aunque para ello se usaron variados instrumentos, los más utilizados, y los que impulsaron buena parte de los reclamos de los países socios, fue la aplicación de licencias no automáticas, valores criterio, derechos antidumping y acuerdos entre privados en distintos sectores ${ }^{123}$.

La utilización de las licencias no automáticas se amplió en 2009, fortaleciendo reclamos por parte de la industria brasileña afectada, que generaron frecuentes reuniones entre las autoridades comerciales de ambos países para abordarlas. A fines de 2009, las licencias argentinas alcanzaban 412 posiciones (a 8 dígitos de la nomenclatura común del MERCOSUR $)^{124}$. Al principio, la reacción del gobierno brasileño había sido cautelosa, dado el contexto de crisis internacional, y sólo había promovido reuniones ministeriales para tratar el tema. Pero, en octubre de ese año, adoptó medidas similares en forma de represalia para con productos perecederos de la industria argentina y, sólo con la acumulación de camiones detenidos en la frontera, las negociaciones oficiales avanzaron hacia la liberación más fluida de las licencias en los dos sentidos hacia fines de $2009^{125}$. Una vez más, se trataba de una distensión lograda a partir de medidas unilaterales y presiones mutuas. El propio INTAL señalaba que en el bloque se priorizaban estas medidas discrecionales en lugar de aprovechar las situaciones de conflicto para instrumentar el tan anunciado MAC, que seguía sin ponerse en funcionamiento, una necesidad "imperiosa al advertirse que buena parte de los conflictos en determinados sectores productivos tienen carácter recurrente" ${ }^{\text {"126. }}$.

Luego de un segundo semestre de 2009 con un alto nivel de conflictos comerciales, la recuperación de las economías y la expansión comercial parecía distender por sí sola las tensiones $^{127}$; pero, otra vez, esta distensión duró poco. Hacia fines de 2010 se evidenciaba un resurgimiento de conflictos y tensiones comerciales en un contexto de recuperación económica global, pero en el que los países del MERCOSUR vieron caer su superávit comercial y su balanza de pagos. Aunque en 2010 no hubo nuevos registros de licencias argentinas, se mantuvieron los existentes y sí se ampliaron a principios de 2011, generando nuevas discusiones entre las autoridades de ambos países ${ }^{128}$. A partir de febrero de 2012, se sumó la exigencia de declaraciones juradas anticipadas de importación, que cubrían la totalidad del universo arancelario y todos los socios comerciales del país ${ }^{129}$. Estas declaraciones reemplazarían, en 2013, las antiguas licencias como instrumento de administración de comercio $^{130}$.

122 Informe MERCOSUR, N 13 , pág. 120-122.

123 Vale recordar que no era el único país que utilizaba licencias no automáticas, sino que también lo hacía Brasil, aunque no aumentó en gran medida su utilización como consecuencia de la crisis. Informe MERCOSUR, $\mathrm{N}^{\circ} 14$, pág. 78-79.

124 Informe MERCOSUR, N ${ }^{0} 15$, pág. 122.

125 Ibidem, pág. 122-123.

126 Informe MERCOSUR, $\mathrm{N}^{0} 14$, pág. 96.

127 Informe MERCOSUR, $\mathrm{N}^{0} 15$, pág. 131.

128 Informe MERCOSUR, N ${ }^{\circ} 16, \mathrm{BID} / \mathrm{INTAL}$, Buenos Aires, diciembre de 2011, pág. $107-108$.

129 Resolución General № 3.252 del 05/01/2012 de la Administración Federal de Ingresos Públicos.

130 Resolución del Ministerio de Economía № 11/2013. 


\section{REFLEXIONES FINALES}

Las RNA al comercio intrarregional han tenido especial repercusión como expresiones de los problemas del MERCOSUR; esto es, de un mercado que pretendía, según el Tratado de Asunción que le da origen, ampliar los mercados nacionales para formar un mercado común regional como medio para el desarrollo económico. Sin embargo, desde los inicios de este proceso de integración, se observó una tensión entre las desgravaciones arancelarias que se hacían efectivas para liberar el comercio y ampliar así el mercado y la aparición de nuevos requisitos para este comercio que, aún sin ser aranceles, reafirmaban las fronteras del mercado nacional. Como se expuso, esta tensión no es exclusiva del proceso de integración, sino que se observa también a nivel internacional, y se funda en la dificultad de definir, identificar y abordar las RNA, problemas comunes del comercio internacional y el regional. Esta dificultad parece ser, a la vez, una elección política, ya que deja la puerta abierta a distintas interpretaciones de los tribunales, que pueden evaluar como legítimas o ilegítimas las medidas comerciales impuestas por distintos países, según sus justificaciones y contextos.

En este marco, desde el inicio del proceso de integración, la normativa del MERCOSUR definió las RNA como instrumentos ilegítimos a los que no debían recurrir los Estados Partes, pero el escaso avance que hubo en su identificación, las limitaciones de los mecanismos de consultas a la Comisión de Comercio, así como la imposibilidad de los tribunales regionales de hacer cumplir sus laudos cuando dictaban eliminarlas, permitió su continua existencia y las naturalizó como parte del mercado común en ciernes.

En el caso de las RNA argentinas, como se observó en la última sección, aquellas que aparecieron una vez concluido el Régimen de adecuación en 1999 parecían justificarse por el contexto de crisis económica que generaba la repentina devaluación de la moneda brasileña; sin embargo, el crecimiento económico que caracterizó a la región a partir de 2002 no evitó su persistencia en sectores determinados, para que volvieran a ampliarse al sentirse los primeros efectos de la crisis económica internacional en 2008. Y esa persistencia hizo que, si por un lado se naturalizaban como parte del proceso, por el otro alimentaban continuamente las críticas al bloque, ya que se leían como un incumplimiento del compromiso de liberalización comercial asumido desde el Tratado de Asunción.

En este escenario, se producía una relación circular entre la dificultad de abordar las RNA normativamente, que tuvo, como efecto, la preferencia de los líderes nacionales de tratarlas caso por caso y negociarlas políticamente; y tal preferencia, que limitó el interés por desarrollar normativa regional que afrontara aquella dificultad. Inclusive cuando existió iniciativa política para establecer el Mecanismo de Adaptación Competitiva como mecanismo bilateral (ya que lo negociaron sólo Argentina y Brasil), ésta no fue suficiente para ponerlo en funcionamiento, redundando, una vez más, en que los problemas sectoriales se enfrentaran con RNA unilaterales y, como consecuencia, con represalias comerciales del país vecino, situación que se trataba (no siempre con resultados satisfactorios para ambas partes) al más alto nivel político. 
La preferencia por la negociación política se ha leído hasta ahora de distintas maneras. Algunos autores la han destacado como una forma de diálogo entre Estados Partes con sistema político presidencial, limitándose a observar la capacidad política de sus líderes para resolver conflictos comerciales relevantes a través de dicho diálogo ${ }^{131}$. Otros la han considerado una muestra de la debilidad del proceso de integración, que al no contar con instituciones regionales eficaces, sólo deja lugar a dichas tratativas ${ }^{132}$. Este recorrido por la normativa y la historia de las RNA argentinas durante los diez años estudiados da pie a otra interpretación, que complejiza esa relación causal, entendiendo que se trata de un refuerzo mutuo (y continuo) entre la dificultad de construir normas e instituciones que afronten de manera eficaz las RNA y la preferencia de los líderes nacionales por negociarlas políticamente. La dificultad de interrumpir este círculo vicioso se hace evidente hasta hoy en día, justificando la necesidad de nuevos estudios sobre integración regional que desmenucen dicho círculo y analicen en profundidad las dinámicas políticas nacionales y regionales que lo provocan ${ }^{133}$.

${ }^{131}$ Malamud, Andrés, "Presidential Democracies and Regional Integration. An Institutional Approach to MERCOSUR (1985-2000)", PhD. Dissertation, European University Institute, Florence, 2003.

${ }_{132}$ Bouzas, Roberto, "MERCOSUR: Regional Governance, Asimetrías e Integración Profunda", ponencia presentada en el seminario de profundización del MERCOSUR y el desafío de las disparidades, BID, Río de Janeiro, 6-7 de julio de 2005. Abundan las referencias a la falta de instituciones supranacionales como una falencia del proceso de integración. Sólo a modo de ejemplo, ver Maito, Miguel Ángel, Reformulación de las instituciones para la eficacia del MERCOSUR en la integración económica, La Ley, Buenos Aires, 2011.

${ }^{233}$ Un primer intento por comprender dichas dinámicas en Gil, Luciana, Dinámicas de la política comercial argentina en el MERCOSUR. El caso del sector calzado (1999-2008), Tesis doctoral, Universidad de Buenos Aires, 2014. 


\section{BIBLIOGRAFIA}

Ablin, Eduardo; Lucángeli, Jorge, "La política comercial argentina: evolución reciente y limitaciones de los instrumentos futuros", Boletín Informativo Techint, octubre de 2000

Ablin, Eduardo; Makuc, Adrián, Comercio Exterior. Buenos Aires, Errepar, Buenos Aires, 1997

Balassa. Béla, "Hacia una Teoría de la Integración Económica", en Wionczek, Miguel, Integración de América Latina, Fondo de Cultura Económica, México, 1964

Barral, Welber, O Brasil e o Protecionismo, Aduaneiras, Sao Paulo, 2002

Baruj, Gustavo; Porta, Fernando, "Políticas de competitividad en la Argentina y su impacto en la profundización del MERCOSUR”, CEPAL, Documento de Trabajo, julio de 2006

Bekerman, Marta; Sirlin, Pablo, "Nuevos enfoques sobre política comercial y sus implicancias para los países periféricos", Desarrollo Económico, Vol. 3, № 134, septiembre de 1994

Bouzas, Roberto, "EI MERCOSUR diez años después ¿Proceso de aprendizaje o déjàvu?", Desarrollo Económico, Vol. 41, № 162, 2001

Bouzas, Roberto, MERCOSUR: Regional Governance, Asimetrías e Integración Profunda", ponencia presentada en el seminario de profundización del MERCOSUR y el desafío de las disparidades, BID, Río de Janeiro, 6-7 de julio de 2005

Briceño Ruiz, José, Rivarola Puntigliano, Andrés; Casas Gragea, Ángel María, Integración latinoamericana y caribeña. Política y economía, Fondo de Cultura Económica, Madrid, 2012

Britti, María Soledad, La Opción de Foro en el Sistema de Solución de Controversias del MERCOSUR, Edición electrónica gratuita, 2009, disponible en www.eumed.net/libros/2009a/516/

Campbell, Jorge (ed.), MERCOSUR. Entre la realidad y la utopía, Grupo Editor Latinoamericano, Buenos Aires, 1999

Cortés, María Julieta; Creus, Nicolás, "Entre la necesidad y la desilusión: Los dilemas de la política exterior argentina hacia Brasil (2005-2009)", en Varios Autores, La política exterior de Cristina Fernández. Apreciaciones promediando su mandato, Cerir/UNR, Rosario, 2010

Costa Vaz, Alcides, Cooperação, integração e processo negociador: a construção do Mercosul, IBRI, 2002

Delgado, Ricardo, "Asimetrías y competencia: Aportes para un rediseño de los instrumentos comerciales", en Kosacoff, Bernardo (coord.), Evaluación del desempeño y aportes para un rediseño del MERCOSUR, CEPAL, Buenos Aires, 2004

Deardorff, Alan V.; Stern, Robert Mitchell, Measurement of Nontariff Barriers, University of Michigan Press, 1998

García de la Cruz, José Manuel (dir.); Lucena, Javier; Sánchez, Ángeles; Gayo, Daniel, La integración productiva en MERCOSUR: Orientaciones para la Unión Europea, Serie Avances de Investigación, № 41, Fundación Carolina CeALCl, Madrid, 2010

Gil, Luciana, Dinámicas de la política comercial argentina en el MERCOSUR. El caso del sector calzado (1999-2008), Tesis doctoral, Universidad de Buenos Aires, 2014 
Jackson, John H.; Davey, Williams J.; Sykes, Jr., Alan O., Legal Problems of International Economic Relations. Cases, Materials and Text, American Casebook Series, West Group, Minnesota, 2002

Lavagna, Roberto, Argentina, Brasil, MERCOSUR. Una Decisión Estratégica 1986-2001, Ciudad Argentina, Buenos Aires, 1998

Centurión López, Aldo, "Restricciones no arancelarias en el MERCOSUR." presentación para el Seminario: "Los nuevos desafíos para la integracion regional", BID/INTAL, Buenos Aires, 2 y de octubre de 2002

Lacerda Prazeres, Tatiana, Comércio internacional e protecionismo. As barreiras técnicas na OMC, Aduaneiras, Sao Paulo, 2003

Lucángeli, Jorge, "La Inserción Argentina en el MERCOSUR", Serie de Estudios, Centro de Estudios para el cambio estructural, septiembre de 1998

Maito, Miguel Ángel, Reformulación de las instituciones para la eficacia del MERCOSUR en la integración económica, La Ley, Buenos Aires, 2011

Malamud, Andrés, "Presidential Democracies and Regional Integration. An Institutional Approach to MERCOSUR (1985-2000)", PhD. Dissertation, European University Institute, Florence, 2003

Malamud, Andrés, "La diplomacia presidencial y los pilares institucionales del MERCOSUR: un examen empírico", Relaciones Internacionales, № 15, octubre de 2010

Nogués, Julio J., "La economía política del proteccionismo y la liberalización en la Argentina", Desarrollo Económico, Vol. 28, № 110, septiembre de 1988

Paikin, Damián, "La Argentina y el MERCOSUR en tiempos de crisis internacional: las bases regionales del modelo kirchnerista", en Sarti, Ingrid et al., Por uma integraçao da América do Sul no século XXI, Volume 1, Fomerco, Rio de Janeiro, 2013

Peña, Félix, "Los grandes objetivos del MERCOSUR: Zona de libre comercio, unión aduanera y mercado común", presentación al Seminario: "15 Anos de Mercosul: avaliaçao e perspectivas", Fundaçao Memorial Da América Latina, Sao Paulo, 17 de marzo de 2006

Sanguinetti, Pablo; Sallustro, Marina, MERCOSUR y el sesgo regional de la política comercial: Aranceles y barreras no tarifarias, Centro de Estudios para el Desarrollo Institucional, marzo de 2000.

Taiana, Jorge, "Objetivos y desafíos de la política exterior argentina", DEP. Diplomacia, Estrategia, Política, junio de 2006.

Valenzuela, Juan Guillermo, "Restricciones no arancelarias en los países de La ALADI", Integración Latinoamericana, Vol. 9, n. 87, enero-febrero de 1984

Vaillant, Marcel, "Profundización del proceso de integración económica en bienes", en Chudnosvky, Daniel; Fanelli, José María (coord.), El desafío de integrarse para crecer, balances y perspectivas del MERCOSUR en su primera década, RED MERCOSUR/Siglo XXI/BID, Madrid, 2001

Vigevani, Tullo; Ramanzini Jr., Haroldo, "Brasil en el centro de la integración”, Nueva Sociedad, febrero de 2009 


\section{ARTíCULOS PERIODÍSTICOS (ordenados por autor y fecha)}

Bermúdez, Ismael, "La diplomacia de presidentes evitó la guerra comercial con el Brasil", Clarín, 01/08/1999.

Kanenguiser, Martín, "Buscan frenar importaciones brasileñas", La Nación, 21 de abril de 2005

Muchnik, Daniel, "La competitividad de la industria local", Clarín, 5 de septiembre de 2005

"La Aduana restringe el acceso de importados", La Nación, 13 de agosto de 2005

“Deben preocuparse las empresas que no invierten”, El Cronista, 2 de septiembre de 2005

"Comenzaron trabas a productos brasileños: inició con calzado", Ámbito Financiero, 14 de septiembre de 2005

"No baja el país barreras al calzado importado de Brasil", Ámbito Financiero, 3 de noviembre de 2005

“Los fabricantes de calzado brasileño demandarán al país”, La Nación, 5 de diciembre de 2005

"Esto es un grave error", Página 12, 2 de febrero de 2006

"Brasil alerta que podría restringir el ingreso de productos argentinos", El Cronista, 7 de febrero de 2006

"Empresarios de Argentina y Brasil buscan hacer las paces", Clarín, 13 de febrero de 2006

DOCUMENTOS y NORMATIVA (ordenados alfabéticamente y por fecha)

ACTA GMC № 04/07

Acuerdo de Complementación Económica (ACE) № 14

Código Aduanero Argentino

Decisión CMC № 3/94

Decisión CMC № 5/94

Decisión CMC № 9/94

Decisión CMC № 10/94

Decisión CMC № 21/94

Decisión CMC № 24/94

Decisión CMC № 22/00

Decisión CMC № 28/00

Decisión CMC № 31/00

Decisión CMC № 57/00

Decisión CMC № 59/00

Decisión CMC № 64/00

Decisión CMC № 22/02

Decisión CMC № 56/10

Decisión CMC № 62/12 
Directiva CCM № 13/95

Directiva CCM № 6/96

Directiva CCM № 17/99

Laudo arbitral № 1/2005

Protocolo Adicional al ACE 14: "Adaptación competitiva, integración productiva y expansión equilibrada y dinámica del comercio"

Resolución ALADI № 70/87

Resolución GMC №34/04

Resolución GMC № 21/05

Resolución GMC № 2/09

Resolución Ministerio de Economía y Obras y Servicios Públicos № 977/99

Resolución del Ministerio de Economía y Finanzas Públicas № 11/2013

Resolución Secretaría de Industria, Comercio y Minería № 150/99

Resolución Secretaría de Industria, Comercio y Minería № 11/99

Resolución Secretaría de Industria, Comercio y Minería № 508/99

Resolución Secretaría de Industria, Comercio y Minería № 617/99

Resolución Secretaría de Industria, Comercio y Minería № 653/99

Resolución Administración Federal de Ingresos Públicos N 565/99

Resolución Administración Federal de Ingresos Públicos º 3.252

Tratado de Asunción

Unión Industrial Argentina, "12ª Conferencia Industrial Argentina. Diez años de crecimiento industrial. Un desafío nacional”, Córdoba, 18, 19 y 20 de octubre, disponible en: http://www.uia.org.ar/download.do?id=785 [consulta: 5 de agosto de 2015]

\section{INFORMES (ordenados por autor y fecha)}

Taccone, Juan José; Nogueira, Uziel (editores), Informe MERCOSUR, $N^{\circ} 7, \mathrm{BID} /$ Intal, Buenos Aires, 2001

Taccone, Juan José; Nogueira, Uziel (editores), Informe MERCOSUR, N 8, BID/Intal, Buenos Aires, 2003

Taccone, Juan José; Nogueira, Uziel (editores), Informe MERCOSUR, N 9, BID/Intal, Buenos Aires 2004

Informe MERCOSUR, N³, BID/Intal, Buenos Aires, 1997

Informe MERCOSUR, N4, BID/Intal, Buenos Aires, 1998

Informe MERCOSUR, N 5 , BID/Intal, Buenos Aires, 1999

Informe MERCOSUR, Nº, BID/Intal, Buenos Aires, 2000

Informe MERCOSUR, N¹0, BID/Intal, Buenos Aires, 2005

Informe MERCOSUR, N¹1, BID/Intal, Buenos Aires, 2007

Informe MERCOSUR, N¹2, BID/Intal, Buenos Aires, 2007 
Informe MERCOSUR, №13, BID/Intal, Buenos Aires, 2009

Informe MERCOSUR, №14, BID/Intal, Buenos Aires, 2009

Informe MERCOSUR, №15, BID/Intal, Buenos Aires, 2011

Informe MERCOSUR, №16, BID/Intal, Buenos Aires, 2011

Informe MERCOSUR, №18, BID/Intal, Buenos Aires, 2013

\section{LISTADO DE ENTREVISTAS (ordenadas alfabéticamente)}

- Barbosa, Rubens, 21 de junio de 2012. Ex Representante de Brasil para la ALADI, Subsecretario de Integración, Comercio Exterior y Asuntos Económicos del Ministerio de Relaciones Exteriores, Coordinador de la Sección Brasileña del Grupo MERCOSUR y coordinador de la sección nacional del MERCOSUR en Itamaraty de 1991 a 1994.

- Barral, Welber, 26 de junio de 2012. Árbitro titular del Tribunal Permanente de Revisión del MERCOSUR (desde 2011); Secretario de Comercio Exterior de Brasil (2007-2011) y profesor y consultor de negociaciones comerciales internacionales.

- Czar de Zalduendo, Susana, 31 de marzo de 2012. Árbitro suplente del Tribunal Permanente de Revisión del MERCOSUR (2004-2008); Asesora externa del Departamento MERCOSUR del Ministerio de Relaciones Exteriores, Comercio Internacional y Culto de la República Argentina; participante de las reuniones del Comité Técnico №8 del MERCOSUR sobre "Restricciones y Medidas no arancelarias"; y profesora de Derecho de la Integración.

- Lavagna, Roberto, 10 de octubre de 2013. Ex Ministro de Economía (2002-2005), ex Secretario de Industria y Comercio (1985-1987), fue embajador ante organismos de Naciones Unidas y de la Organización Mundial de Comercio, así como negociador-jefe del MERCOSUR.

- Meira, Frederico, 12 de junio de 2012. Representante del Departamento de Relaciones Internacionales y Comercio Exterior de FIESP.

- Peirano, Miguel, 19 de mayo de 2014. Ex asesor de la CIC, ex Secretario de Industria (20052007) y ex Ministro de Economía (2007). 


\section{LIBROS}

* 1. CERIR, La Política Exterior del Gobierno de Menem: Seguimiento y reflexiones al promediar su mandato. Ediciones CERIR. Rosario, 1994. 396 páginas. Disponible on line en: http://www.cerir.com.ar/libro.php?id=0000004

* 2. LECHINI DE ALVAREZ, Gladys, Las relaciones Argentina-Sudáfrica desde el proceso hasta Menem. Ediciones CERIR. Rosario, 1995. 130 páginas. Disponible on line en: http://www.cerir.com.ar/libro.php?id=0000002

* 3. COLACRAI, Miryam, El Ártico y la Antártida. Su rol en las relaciones Internacionales. Su relevancia desde la perspectiva ambiental. CERIR - Centro de Estudios en Relaciones Internacionales de Rosario. CECAR - Centro de Estudios Canadienses de Rosario. Rosario, 1998. 187 páginas. Disponible on line en: http://www.cerir.com.ar/libro.php?id=0000008

* 4. CERIR, La Política Exterior Argentina 1994/1997. Ediciones CERIR. Rosario, 1998. 338 páginas. Disponible on line en: http://www.cerir.com.ar/libro.php?id=0000007

* 5. ZUBELZU DE BACIGALUPO, Graciela, La Argentina y las Repúblicas Post-soviéticas. La Vinculación Bilateral con Rusia, Ucrania, Armenia y el caso de Turkmenistán. Ediciones CERIR. Rosario, 1999. 191 páginas. Disponible on line en: http://www.cerir.com.ar/libro.php?id=0000009

* 6. BUSSO, Anabella, Las relaciones Argentina - Estados Unidos en los noventa. El caso Cóndor II. Ediciones CERIR. Rosario, 1999. 168 páginas. Disponible on line en: http://www.cerir.com.ar/libro.php?id=0000011

* 7. BONOMELLI, Graciela, Argentina ante la era del Pacífico. El desafío de competir en Japón. Ediciones CERIR. Rosario, 1999. 192 páginas Disponible on line en: http://www.cerir.com.ar/libro.php?id=0000010

* 8. CABEZA, Marta, Italia y Argentina. Las claves de una relación privilegiada. La evolución de la vinculación bilateral desde la redemocratización argentina. Consolato Generale d'Italia. Instituto Italo-Latinoamericano. Ediciones CERIR, Rosario, 2000. 102 páginas. Disponible on line en: http://www.cerir.com.ar/libro.php?id=0000014

* 9. COLACRAI, Miryam (Compiladora) Relaciones Internacionales. Viejos temas, nuevos debates. Ediciones CERIR. Rosario, 2001. 201 páginas. Disponible on line en: http://www.cerir.com.ar/libro.php?id=0000016

* 10. CERIR. La Política Exterior Argentina 1998-2001. El cambio de gobierno ¿Impacto o irrelevancia? Ediciones CERIR. Rosario, 2001. 400 páginas. Disponible on line en: http://www.cerir.com.ar/libro.php?id=0000104

11. CERIR. La Política Exterior Argentina del gobierno de Kirchner. Ediciones CERIR. UNR Editora. Tomo IV. Volumen I 297 páginas. Volumen II. 365 páginas. Rosario, 2006

* 12. BUSSO, Anabella (compiladora), Fuerzas profundas e identidad. Reflexiones en torno a su impacto sobre la política exterior. Un recorrido de casos. Tomo 1. Editora UNR, 1 ra. edición, Universidad Nacional de Rosario. Rosario, 2008 (E-book). Disponible on line en: http://www.cerir.com.ar/libro.php?id=0000102

* 13. CERIR. La Política Exterior de Cristina Fernández. Apreciaciones promediando su mandato. Ediciones CERIR. UNR Editora, Rosario, 2010. 488 páginas

* 14. BUSSO, Anabella (compiladora), Fuerzas profundas e identidad. Reflexiones en torno a su impacto sobre la política exterior. Un recorrido de casos. Tomo 2. Editora UNR, Universidad Nacional de Rosario. Rosario, 2010 (E-book). Disponible on line en: http://www.cerir.com.ar/libro.php?id=0000142

15. CERIR. La Política Exterior de Cristina Fernández al finalizar su mandato. Ediciones CERIR. UNR Editora, Rosario, 2015. 517 páginas

\footnotetext{
* El texto completo de los libros señalados con el asterisco está disponible en la página web www.cerir.com.ar
} 
1. CABEZA, Marta Graciela, La cooperación descentralizada de las provincias y regiones, Editorial Académica Española (EAE), 2011, 96 páginas

2. LORENZINI, María Elena, La estrategia de inserción internacional de Chile en el hemisferio, Editorial Académica Española (EAE), 2011, 148 páginas

3. WEITZ, Darío, Medio Ambiente: Acuerdos Multilaterales y Proteccionismo, Editorial Académica Española (EAE), 2011, 100 páginas

4. BOLOGNA, Alfredo Bruno, Dos modelos de inserción de Argentina, Editorial Académica Española (EAE), 2011, 92 páginas

5. NETRI, Bruno, Derecho Penal Internacional, Editorial Académica Española (EAE), 2011, 496 páginas

6. BEAUGÉ, María Fabiana, Acuíferos Transfronterizos: La necesidad de Cooperación e Integración para su protección, Editorial Académica Española (EAE), 2011, 120 páginas

7. BAEZ, Nelevis, Gestión del MERCOSUR sobre las Migraciones Laborales (1991-2010), Editorial Académica Española (EAE), 2011, 188 páginas

8. MARINUCCI, Elsa, Negociaciones multilaterales sobre agricultura, Editorial Académica Española (EAE), 2012, 88 páginas

LIBROS PUBLICADOS EN EL MARCO DEL CONVENIO EDITORIAL ACADÉMICA ESPAÑOLA (EAE) - CERIR *

9. FABANI, Ornela, El Consejo de Cooperación de Estados Árabes del Golfo, Editorial Académica Española (EAE) - CERIR, 2012, 172 páginas

10. MARTINS MONGE, Daniele, Identidad Regional en el MERCOSUR e Industrias Culturales, Editorial Académica Española (EAE) - CERIR, 2012, 124 páginas

11. GATTI, Lidia, Planteos de reforma de las Naciones Unidas, Editorial Académica Española (EAE) CERIR, 2012, 116 páginas

12. CABALLERO SANTOS, Sergio, Integración regional y MERCOSUR, Editorial Académica Española (EAE) - CERIR, 2012, 108 páginas

13. CARABAJAL, Juan José, Cooperación Internacional y Sociedad Civil, Editorial Académica Española (EAE) - CERIR, 2012, 168 páginas

14. FALCÓN, Roberto, Integración y Derecho en la Unión Europea, Editorial Académica Española (EAE) - CERIR, 2012, 120 páginas

15. FARCUH, Diana, La Liga de los Estados Árabes y su posición durante la invasión a Irak, Editorial Académica Española (EAE) - CERIR, 2012, 136 páginas

16. MONTEQUIN, Adriana Margarita, El Foro Consultivo Económico y Social del MERCOSUR, Editorial Académica Española (EAE) - CERIR, 2012, 168 páginas

17. OLIVA, Carla Verónica, China: reforma económica y estrategia de incorporación a la OMC, Editorial Académica Española (EAE) - CERIR, 2012, 128 páginas

18. SILVA ESPINOSA, Iván, Estado-nación y construcción de interdependencia económica, Editorial Académica Española (EAE) - CERIR, 2012, 144 páginas

19. COLACRAI, Miryam, Continuidades y cambios en la Política Antártica Argentina 1959-2001, Editorial Académica Española (EAE) - CERIR, 2012, 268 páginas

20. SICA, Cristina, Armonización legislativa, Editorial Académica Española (EAE) - CERIR, 2012, 148 páginas

21. MARINUCCI, Elsa, Negociaciones sobre agricultura en la Organización Mundial de Comercio, Editorial Académica Española (EAE) - CERIR, 2012, 408 páginas

22. VELÁZQUEZ, Claudia Analía, La Tesis de los optimistas, Editorial Académica Española (EAE) CERIR, 2012, 168 páginas

"Se pueden adquirir online en: www.morebooks.es 


\section{PUBLICACIONES PERIÓDICAS *}

\section{CUADERNOS DE POLITICA EXTERIOR ARGENTINA}

\section{Serie: ESTUDIOS}

1. Los principios de la política exterior india y los espacios para la posible cooperación con Argentina por Nora B. LOPEZ. Rosario, diciembre de 1985. 28 págs.

2. Argentina-Medio Oriente: posibilidades para la cooperación Sur-Sur por Silvia SUDOL. Rosario, febrero de 1986.38 págs.

3. El mundo desarrollado en la Antártida: las superpotencias y la Comunidad Económica Europea. Ejemplos de cooperación selectiva por Miryam COLACRAI de TREVISAN. Rosario, junio de 1986. 45 págs.

4. Argentina-Africa: la crisis sudafricana por Gladys LECHINI de ALVAREZ. Rosario, junio de 1988. 48 págs.

5. Actores privados y estatales en la relación Argentina-Estados Unidos por Alicia FROHMANN. Rosario, setiembre de 1989. 57 págs.

6. El Apartheid y la política exterior sudafricana. Una percepción desde argentina por Gladys LECHINI de ALVAREZ. Rosario, octubre de 1992. 54 págs.

7. La Política Exterior Argentina hacia Estados Unidos (1989-1993): Reflexiones para su análisis por Anabella BUSSO. Rosario, marzo de 1993. 89 págs.

\section{Serie: DOCUMENTOS DE TRABAJO}

* 1. Teorías y propuestas de relaciones internacionales para los países del Sur por Alfredo Bruno BOLOGNA. Rosario, septiembre de 1987. 42 págs.

2. Teoría, epistemología y metodología de las relaciones internacionales por Guillermo FIGARI. Rosario, diciembre de 1987. 46 págs.

3. Enfoques teóricos y doctrinarios que dominaron las relaciones entre los países del Cono Sur durante los setenta. (Su aplicación a la problemática antártica) por Miryam COLACRAI. Rosario, marzo de 1988. 48 págs.

4. Estados Unidos y la redemocratización latinoamericana: los condicionantes externos por Anabella BUSSO. Rosario, septiembre de 1990. 58 págs.

5. Japón y América Latina: un espacio de cooperación alternativo por Graciela BONOMELLI. Rosario, octubre de 1991.82 págs.

* 6. Las provincias y sus relaciones externas. ¿Federalización de la Política Exterior o protagonismo provincial en las relaciones internacionales? por Miryam COLACRAI y Graciela ZUBELZU de BACIGALUPO. Rosario, diciembre de 1994. 52 págs.

7. EI MERCOSUR de las post-transición. Balance y perspectivas, por María Alejandra Saccone. Rosario, noviembre de 1995. 58 págs.

8. La Comunidad de Estados Independientes: avances y retrocesos en el difícil camino de la integración por Graciela ZUBELZU de BACIGALUPO. Rosario, diciembre de 1995. 37 págs.

\footnotetext{
* El texto completo de los Cuadernos de Política Exterior Argentina señalados con el asterisco está disponible en la página web www.cerir.com.ar
} 
9. EI MERCOSUR de las post-transición. Balance y perspectivas. II Parte por María Alejandra SACCONE. Rosario, noviembre de 1996.

10. A ocho años del alineamiento: un análisis de la política exterior argentina hacia los Estados Unidos por Anabella BUSSO. Rosario, diciembre de 1997. 103 págs.

11. Las relaciones República Popular China - Taiwán (1989-1999) por Carla OLIVA. Rosario, marzo del 2000.

\section{Serie: INFORMES SOBRE PROYECTOS DE INVESTIGACION}

1. El análisis de la Política Exterior Argentina desde la perspectiva de las relaciones internacionales por Roberto A. MIRANDA. Rosario, diciembre de 1988. 45 págs.

* 2. Dos modelos de Inserción de la Argentina en el mundo: las presidencias de Alfonsín y Menem por Alfredo Bruno BOLOGNA. Rosario, diciembre de 1991. 95 págs.

\section{Serie: DOCENCIA}

1. "Algunas claves teóricas para comprender el realismo y sus límites en las relaciones internacionales" por Gladys LECHINI de ÁLVAREZ, Anabella BUSSO y Miryam COLACRAI. Rosario, agosto de 1988. 33 págs.

* 2. "Relaciones Internacionales Contemporáneas" por Alfredo Bruno BOLOGNA y Anabella BUSSO. Rosario, setiembre de 1988. 56 págs.

3. "Tipología para el análisis de los conflictos en América Latina" por Alfredo Bruno BOLOGNA. Rosario, mayo de 1990. 49 págs.

4. "La Administración republicana Nixon-Ford y sus relaciones con América Latina" por Alfredo Bruno BOLOGNA. Rosario, setiembre de 1991. 49 págs.

* 5. "Política Exterior de la República Popular China". Primera Parte. Evolución de la revolución (1790-1949)" por Gustavo MARINI. Rosario, noviembre de 1991. 30 págs.

* 6. "Política Exterior de la República Popular China". Segunda Parte. Alianza con la Unión Soviética (1949-1960) por Gustavo MARINI. Rosario, noviembre de 1991. 59 págs.

* 7. "Política Exterior de la República Popular China". Tercera Parte. Impugnación al esquema bipolar (1960-1971) por Gustavo MARINI. Rosario, noviembre de 1991. 69 págs.

8. "El Islam. Su influencia en la idiosincrasia de los pueblos de Medio Oriente" por Magdalena CARRANCIO y Lidia GATTI. Rosario, diciembre de 1991. 42 págs.

9. "El Tratado de Asunción. MERCOSUR". Bibliografía y Documentación. Rosario, febrero de 1992. 72 págs.

10. "La respuesta germana a los desafíos de Europa Oriental a fines de la década de los ochenta" por Mónica APARICIO. Rosario, marzo de 1992. 56 págs.

* 11. "El Sahara Occidental: ¿fin del colonialismo en África?" por Magdalena CARRANCIO. Rosario, abril de 1992. 80 págs.

12. "Poder, Estado-nación y regímenes en un orden internacional en transición" por Miryam COLACRAI, Graciela ZUBELZÚ de BACIGALUPO y Sandra BUSTAMANTE. Rosario, junio de 1992. 39 págs.

13. "Japón, un sendero hacia el crecimiento: las etapas de su desarrollo económico" por Graciela BONOMELLI. Rosario, junio de 1992. 51 págs. 
14. "La cuestión alemana desde la Segunda Guerra Mundial" por Mónica APARICIO. Rosario, junio de 1992. 40 págs.

* 15. "El conflicto árabe-israelí: desde sus orígenes hasta los Acuerdos de Camp David" por Lidia GATTI. Rosario, julio de 1992. 87 págs.

16. "Los fundamentos económicos, políticos y sociales del actual crecimiento japonés" por Graciela BONOMELLI. Rosario, setiembre de 1992. 47 págs.

17. "La Política Exterior canadiense hacia América Latina" por Gladys LECHINI de ÁLVAREZ. Rosario, setiembre de 1992. 23 págs.

18. "Las Leñas: un nuevo impulso a la Marcha del Mercado Común del Sur". Bibliografía sobre MERCOSUR, por Elsa MARINUCCI. Rosario, octubre de 1992. 72 págs.

19. "Un ejemplo de la persistencia de fuerzas desintegrativas en el sistema internacional: el conflicto de Nagorno-Karabaj" por Graciela ZUBELZÚ de BACIGALUPO. Rosario, noviembre de 1992. 28 págs.

20. "La transición hacia el Mercado Común del Sur (MERCOSUR): Luces en la sombra" por María Alejandra SACCONE, Anabella BUSSO y Claudia GIACCONE. Rosario, diciembre de 1992. 115 págs.

21. "Yugoslavia y la ausencia de un modelo integrativo: una larga historia de desencuentros y posiciones enfrentadas" por Silvina MICHELSON de PECHARA. Rosario, julio de 1993. 36 págs.

22. "Política Exterior de la República Popular China". Cuarta Parte (1971-1989) por Gustavo MARINI. Rosario, julio de 1993. 105 págs.

23. "Del Mercado único a la Unión Europea" por Pedro ROMERO. Rosario, agosto de 1993. 45 págs.

24. "Conceptos y técnicas básicas de Comercio Exterior" por Graciela BONOMELLI. Rosario, noviembre de 1993. 65 págs.

25. "Percepciones y propuestas: cuántos nacionalismos hay en Rusia" por Graciela ZUBELZÚ de BACIGALUPO. Rosario, diciembre de 1993. 52 págs.

26. "Los golpes de estado en América Latina en la presente década" por Alfredo Bruno BOLOGNA. Rosario, abril de 1994. 65 págs.

27. "El desarrollo industrial japonés y su management" por Graciela BONOMELLI. Rosario, agosto de 1994. 43 págs.

28. "Política Exterior de América Latina a través de las reuniones cumbres del Grupo de Río. Las relaciones con la Unión Europea (1986-1994)" por Alfredo Bruno BOLOGNA. Rosario, diciembre de 1994. 47 págs.

29. "Diseño de proyecto aplicado a un caso práctico. Creación de una Red Informática de Proyectos Empresariales provinciales" por Graciela BONOMELLI. Rosario, marzo de 1995. 60 págs.

30. "Cooperación nuclear entre Argentina y Brasil" por Claudia A. GIACCONE. Rosario, junio de 1995. 45 págs.

31. "El medio ambiente y las Relaciones Internacionales" por Miryam COLACRAI. Rosario, octubre de 1995. 69 págs.

32. "Estudio preliminar sobre el proceso de toma de decisiones en la Unión Europea" por Penélope FALCÓN NEYRA. Rosario, diciembre de 1995. 33 págs. 
33. "Japón en el Nuevo Orden Mundial: Tendencias en su agenda de Política Exterior" por Graciela BONOMELLI. Rosario, marzo de 1996. 41 págs.

34. "Capacidades técnicas y de gobierno en las privatizaciones de Menem y Collor de Melo" por Osvaldo IAZZETTA. Rosario, mayo de 1996. 48 págs.

35. "Agenda de América Latina" por Alfredo Bruno BOLOGNA. Rosario, octubre de 1996. 102 págs.

36. "Yugoslavia: Ia desintegración de la Integración" por Mariela CEJAS. Rosario, noviembre de 1996. 34 págs.

37. "Los superbloques económicos: Área de Libre Comercio de América" por Alfredo Bruno BOLOGNA. Rosario, marzo de 1997. 20 págs.

38. "Los superbloques económicos: Asia Pacific Economic Cooperation" por Alfredo Bruno BOLOGNA. Rosario, diciembre de 1997. 68 págs.

39. "La Crisis del Golfo Pérsico". Análisis de la Toma de Decisión para el envío de Naves por Parte del Gobierno Argentino por Magdalena CARRANCIO. Rosario, marzo de 1998. 47 págs.

40. "Material de Consulta y divulgación". Realizado por miembros del CERIR y publicados en el diario "La Capital" de Rosario. Rosario, junio de 1998. 100 págs.

41. "El proceso de formación en la integración militar en el MERCOSUR" por Natalia BOLOGNA. Rosario, junio de 1998. 53 págs.

42. "Organismos regionales y cooperación internacional en Medio Oriente" por Magdalena CARRANCIO. Rosario, julio de 1998. 50 págs.

* 43. "La guerra en los Balcanes: ¿del conflicto a la paz? por María Julieta CORTÉS. Rosario, julio de 1998. 37 págs.

44. "Doctrinas de Política Internacional". Recopilación realizada por Alfredo Bruno BOLOGNA. Rosario, agosto de 1998. 40 págs.

* 45. "El Conflicto de Chechenia: Evolución y perspectivas" por Natalia BOLOGNA. Rosario, septiembre de 1998. 46 págs.

46. "La Teoría de la Dependencia como una Teoría Latinoamericana de las Relaciones Internacionales" por María Julieta CORTÉS. Rosario, septiembre de 1998. 32 págs.

47. "Estado-nación, formulación clásica y práctica latinoamericana: notas para un contrapunto. A propósito de la supranacionalidad en el MERCOSUR" por Iván SILVA ESPINOSA. Rosario, octubre de 1998. 20 págs.

48. "La Política Exterior Argentina frente a la Integración. Razones y objetivos de su participación en la ALALC, el PICE y el MERCOSUR", por Javier E. BINAGHI. Rosario, mayo de 1999. 40 págs.

49. "La trayectoria política de los servicios secretos rusos y el escenario post-soviético", por Sebastián T. OVEJERO SAGARZAZU. Rosario, julio de 1999. 60 págs.

50. "Turquía y Medio Oriente. Entre la cooperación y la confrontación", por Luciano ZACCARA. Rosario, agosto de 1999. 37 págs.

51. "El sistema político de la República Popular China (1949-1998)", por Natalia BOLOGNA. Rosario, octubre de 1999. 34 págs.

52. "Estudio de un caso práctico. Promoción de las Exportaciones en la Provincia de Santa Fe: las políticas públicas desarrolladas por las agencias del estado y sus relaciones interorganizadas", por Graciela BONOMELLI. Rosario, noviembre de 1999.30 págs. 
53. "Instrumentos de Asistencia para desarrollar el perfil exportador de las PYMES", por Graciela BONOMELLI. Rosario, diciembre de 1999. 18 págs.

54. "El mapa de la integración africana. El caso de la SADC", por Gladys LECHINI. Rosario, diciembre de 1999. 30 págs.

55. "Caracterización de las PYMES: ventajas y desventajas en su inserción comercial internacional”, por Graciela BONOMELLI. Rosario, enero del 2000. 20 págs.

* 56. "La pequeña y media empresa y su capacidad de inserción internacional: Políticas públicas e instrumentos para desarrollar el perfil exportador", por Graciela BONOMELLI. Rosario, febrero del 2000. 19 págs.

57. "Hipótesis de conflicto. Año 1997", por Narciso BINAYÁN CARMONA. Rosario, marzo del 2000. 36 págs.

58. "Hipótesis de conflicto. Año 1998", por Narciso BINAYÁN CARMONA. Rosario, marzo del 2000. 70 págs.

59. "Hipótesis de conflicto. Año 1999", por Narciso BINAYÁN CARMONA. Rosario, marzo del 2000. 65 págs.

60. "Las negociaciones MERCOSUR - Unión Europea en materia agrícola. Forma y perspectiva”, por Rubén PAREDES RODRÍGUEZ. Rosario, abril del 2000. 29 págs.

61. "Las PYMES y las normas de calidad: nuevas herramientas para la competitividad", por Marta CABEZA. Rosario, septiembre del 2000. 22 págs.

62. "La cuestión antártica en la política exterior argentina: desarrollos recientes y proyección de tendencias. Entre el consenso multilateral y la persistencia de desacuerdos bilaterales", por Miryam COLACRAI. Rosario, octubre del 2000.

63. "Zonas francas", por Fernando RUILOVA, Rosario, junio del 2001. 20 págs.

"64. "Nuevas percepciones del sistema internacional en la post guerra fría", por Alfredo Bruno BOLOGNA. Rosario, julio de 2001. 75 págs.

65. "El Conflicto de los Balcanes. La guerra de Kosovo 1999" por María Julieta CORTÉS y Vera TABAKOVIC. Rosario, marzo de 2002. 33 págs.

66. "Comercio Exterior Argentino: la década del 90' y las reformas post-devaluación" por Graciela BONOMELLI, Marta CABEZA y María Victoria BORSINI. Rosario, septiembre de 2002. 40 págs.

67. "Mercosur: las trabas al comercio" por Gisela M. CANAVESIO. Rosario, diciembre 2002. 25 págs,

68. "La Doctrina Bush". Estrategia de Seguridad Nacional de Estados Unidos de América. Rosario, marzo 2003. 37 págs,

69. "Hipótesis de conflicto. Año 2000" por Narciso BINAYÁN CARMONA. Rosario, agosto de 2003. 63 págs,

70. "Hipótesis de conflicto. Año 2001" por Narciso BINAYÁN CARMONA. Rosario, septiembre de 2003. 75 págs,

71. "América Latina y Asia del Este: hacia una mayor relación birregional" por María Victoria BORSINI. Rosario, noviembre de 2003. 26 págs,

72. "La Negociación Internacional. Casos prácticos y herramientas para el aprendizaje activo" por Marta CABEZA. Rosario, diciembre de 2003. 34 págs, 
* 73. "Reflexiones en torno al Régimen Antártico y las relaciones argentino-chilenas" por Miryam COLACRAI. Rosario, diciembre de 2003. 48 págs.

* 74. "La estrategia de inserción comercial de la República de Chile: el caso del Tratado de Libre Comercio con Estados Unidos" por María Elena LORENZINI. Rosario, marzo de 2004. 36 págs.

* 75. "Afganistán y el régimen Talibán" por Marcela Gabriela MENCIA. Rosario, octubre de 2004. 48 págs.

* 76. "La estructura del Poder Mundial en el Siglo XXI: el efecto BRIC: Brasil, Rusia, India y China. ¿Realidad o fantasía? Política Exterior de la India” por Gerardo Manuel BIRITOS. Rosario, noviembre de 2004. 20 págs.

* 77. "La política comercial argentina y los consorcios de exportación" por Marta CABEZA y Evangelina MARTíNEZ. Rosario, diciembre de 2004. 22 págs.

* 78. "Secuencia operativa de Exportación e Importación en Argentina" por Mariela C. VISENTIN. Rosario, diciembre de 2004. 28 págs.

* 79. "El Medio Oriente ante el terrorismo internacional: una mirada desde los tratados internacionales" por Bruno NETRI. Rosario, marzo de 2005. 37 págs.

* 80. "Las inversiones de la República Popular China en Brasil y la Argentina" por Carla OLIVA. Rosario, junio de 2005. 28 págs.

* 81. "La incidencia de las fuerzas profundas en el proceso de construcción identitaria de Irán, Irak y Afganistán" por Rubén PAREDES RODRÍGUEZ. Rosario, septiembre de 2005. 65 págs.

* 82. "Los optimistas y el fin de la historia: análisis de la tesis de Francis Fukuyama, aportes posteriores y críticas" por Claudia VELÁZQUEZ. Rosario, diciembre de 2005. 25 págs.

* 83. "Derecho de obtentor de variedades vegetales: un instituto en retroceso" por Arturo Guillermo Rivera. Rosario, marzo de 2006. 33 págs.

* 84. "Planteo de reforma de las Naciones Unidas: análisis sobre propuestas y logros en torno a una mayor participación de las ONGs" por Lidia V. GATTI. Rosario, junio de 2006. 88 págs.

* 85. "China: reforma económica y estrategia de incorporación a la Organización Mundial del Comercio. La combinación de factores internos y externos" por Carla OLIVA. Rosario, julioseptiembre 2006. 101 páginas.

* 86. "El Parlamento del MERCOSUR. Una comparación con la experiencia europea" por María Victoria ÁLVAREZ MACÍAS. Rosario, octubre - diciembre de 2006. 42 páginas.

* 87. "Rusia y las Repúblicas pos-soviéticas: ¿Influencia compartida, influencia debilitada, influencia acrecentada" por Graciela ZUBELZÚ. Rosario, enero - marzo de 2007. 37 páginas.

* 88. "El Foro Consultivo Económico y Social del MERCOSUR: Un análisis de su evolución, percepciones y expectativas de la Sección Nacional Argentina" por Adriana MONTEQUIN. Rosario, abril - junio 2007. 148 páginas.

* 89. "Integración y Derecho en la Unión Europea” por Roberto FALCÓN. Rosario, julio-setiembre 2007. 101 páginas.

* 90. "El Poder Legislativo en la definición de la Política Exterior Argentina. El caso de los hielos continentales patagónicos" por Mariel R. LUCERO. Rosario, octubre-diciembre 2007. 110 páginas.

* 91. "La Unión de los países del Sur en las propuestas de integración del primer peronismo (1946-1948)" por Carlos Nahuel ODDONE. Rosario, enero-marzo 2008. 114 páginas 
* 92. "El Frente Amplio Uruguayo, las matrices de política exterior y los modelos de inserción internacional subyacentes en su interior" por Matías CASTELLANO. Rosario, abril-junio 2008 № 92.165 páginas.

* 93. "Camp David 1978. Análisis de una negociación" por Alejandra ALBIZU. Rosario, julioseptiembre de 2008. 46 páginas.

* 94. "El sector energético ruso: privatización, reformas y expansión externa. Su proyección en América Latina" por Graciela ZUBELZÚ. Rosario, octubre-diciembre de 2008. 54 páginas.

* 95. "La cooperación internacional en la gestión del agua dulce: el caso de la Cuenca del río Pilcomayo" por Natalia CEPPI. Rosario, enero-marzo 2009. 36 páginas.

* 96. "La alianza estratégica argentino-brasileña en la política exterior de Itamaraty" por Sandro SCHTREMEL. Rosario, abril-junio 2009. 146 páginas.

* 97. "Negociaciones sobre agricultura en la Ronda Uruguay: la influencia del Grupo Cairns" por Elsa MARINUCCI. Rosario, julio-septiembre 2009. 25 páginas.

* 98. "EI MERCOSUR ideacional: un enfoque complementario para la integración regional sudamericana" por Sergio CABALLERO SANTOS. Rosario, octubre-diciembre 2009. 21 páginas.

* 99. "Nuevos contornos / Renovados mapas. Actores transnacionales y unidades sub-estatales en el escenario político internacional" por Ricardo César CARBALLO. Rosario, enero-marzo 2010. 74 páginas.

* 100. "La política migratoria estadounidense post 9/11: proyecciones y el poder excedente" por Lila GARCÍA. Rosario, abril-junio 2010. 33 páginas.

* 101. "La cooperación en el ámbito nuclear entre Argentina e Irán (1986-1997)" por Paulo BOTTA. Rosario, julio-septiembre 2010. 34 páginas.

* 102. "La necesidad de la cooperación e integración en la protección de los Acuíferos Transfronterizos" por María Fabiana BEAUGÉ. Rosario, octubre-diciembre 2010. 68 páginas.

* 103. "La cohesión social en la cooperación al desarrollo de la Comunidad Europea hacia América Latina" por Mara ALACQUA. Rosario, enero-marzo 2011. 182 páginas.

* 104. "Política exterior argentina y MERCOSUR. Etapa temprana (1983-1989). 'Derrumbar dictaduras para edificar integración’” por Ricardo César CARBALLO. Rosario, abril-junio 2011. 40 páginas

* 105. "Identidad y nación en el pensamiento político de la generación del '37: una mirada hacia una nueva forma de democracia" por María Belén CAMPERO. Rosario, julio-septiembre 2011. 49 páginas

* 106. "Fuerzas Armadas en Venezuela y Honduras. ¿Autonomía o protección norteamericana?" por Elliot SUCARI. Rosario, octubre-diciembre 2011. 37 páginas

* 107. "Los profesionales de Estado en Argentina: el caso del Instituto del Servicio Exterior de la Nación (ISEN)" por Natalia RIZZO. Rosario, enero-marzo 2012. 22 páginas

* 108. "FARC 2012: ¿agrupación guerrillera, narcotraficante o parte del terrorismo internacional? Desafíos de un hibrido que aglutina 'de todo un poco'” por Emilse CALDERÓN. Rosario, abriljunio 2012. 28 páginas

* 109. "El Estado en el marco de los Procesos de Integración Regional: ¿renuncia o ejercicio extendido de soberanía?" por Giovanny CARDONA MONTOYA. Rosario, julio-septiembre 2012. 20 páginas

* 110. "Cooperación en seguridad entre las monarquías del Golfo. Un análisis a tres décadas de la creación del CCG" por Ornela FABANI. Rosario, octubre-diciembre 2012. 50 páginas 
* 111. "El continente americano durante la Gran Guerra. Las miradas de Manuel Ugarte, Ernesto Quesada, Alfredo Palacios y Leopoldo Lugones" por Silvina CORMICK. Rosario, enero-marzo 2013. 23 páginas

* 112. "Universidad y política exterior. La formación de expertos y diplomáticos en la Facultad de Ciencias Económicas, Comerciales y Políticas de Rosario, 1920-1968” por Miguel Ángel DE MARCO (h), Rosario, abril-junio 2013. 32 páginas

* 113. "El referéndum de 2013 en Malvinas: una oportunidad para reforzar la posición argentina" por Luciano PEZZANO, Rosario, julio-septiembre 2013. 36 páginas

* 114. "Los partidos políticos argentinos y el MERCOSUR" por Hugo Daniel RAMOS, Rosario, octubre-diciembre 2013. 23 páginas

* 115. "La Argentina de los ' 90 y el ALCA. Diferentes lecturas desde las tradiciones clásicas de las relaciones internacionales" por Alejandro M. JAQUENOD, Rosario, enero-marzo 2014. 25 páginas

* 116. "La Formación del Funcionario Diplomático Uruguayo en el Siglo XXI. Diagnóstico y Propuestas para la Gobernanza Política" por Wilson FERNÁNDEZ LUZURIAGA, Rosario, abriljunio 2014. 75 páginas

* 117. "Avances y retrocesos en las negociaciones entre palestinos e israelíes en la post guerra fría" por Ornela FABANI, Rosario, julio-septiembre 2014. 30 páginas

* 118. "Una revisión del sistema de partidos. El actual escenario europeo" por Alejandra P. DIAZ, Rosario, octubre-diciembre 2014. 30 páginas

* 119. "La cooperación internacional descentralizada del Poder Ejecutivo de la Pronvincia de Entre Ríos: acciones y motivaciones, 1994-2013" por Cynthia CABROL, Rosario, enero-marzo 2015. 94 páginas

* 120. "Las restricciones no arancelarias argentinas en el MERCOSUR: normas y política en los conflictos comerciales" por Luciana GIL, Rosario, abril-junio 2015. 36 páginas 


\section{CUADERNOS DE POLÍTICA EXTERIOR ARGENTINA}

\section{Política editorial}

1. La presentación debe realizarse en formato electrónico de acuerdo a las siguientes especificaciones:

Papel Tamaño A4

Párrafo con una separación de espacio y medio. Tipo de letra: Arial. Tamaño: 10.

2. Los trabajos deberán ser acompañados de un Resumen del contenido, en español y en inglés, con una extensión máxima de 200 palabras. En los dos idiomas se deben incluir el título y las palabras claves para su registro bibliográfico.

3. Toda aclaración con respecto al trabajo (presentación previa, colaboradores, agradecimientos, etcétera) se indicará con un asterisco en el título remitiendo al pie de página. Asimismo, se debe consignar el título académico, la pertenencia institucional y el correo electrónico, en nota al pie de página mediante doble asterisco.

4. Técnica de las citas: pueden seguirse dos procedimientos:

- Citas al pie de página, en cuyo caso se debe seguir una numeración correlativa, procurando no omitir datos. Se sugiere este orden: a) Nombre y apellido del autor; b) Título de la obra, en cursiva; c) Volumen o tomo; d) Traducción: Trad. Nombre y apellido del traductor; e) Editorial; f) Ciudad sin abreviar y fecha de publicación; g) Número de la página consultada. Si se trata de un artículo, éste irá entre comillas, poniéndose en cursiva la obra o la revista en la que fue publicado.

- Citas en el texto, en cuyo caso se debe colocar entre paréntesis el apellido del autor, año de publicación y página correspondiente.

5. El trabajo debe incluir una sección final denominada Bibliografía, donde se enumeren todas las publicaciones y documentos citados en el texto.

6. Sólo serán considerados para su publicación trabajos inéditos en idioma español. La traducción de trabajos en otros idiomas quedará a cargo del autor.

7. La publicación no se hace responsable por originales no publicados. En ese caso puede ser solicitada la devolución.

8. Las opiniones vertidas son de exclusiva responsabilidad de sus autores y no reflejan, necesariamente, aquella de los Cuadernos de Política Exterior Argentina.

9. Los trabajos son sometidos a evaluación de expertos mediante el sistema de doble ciego.

10. La publicación Cuadernos de Política Exterior Argentina está Indexada en Latindex Catálogo, Nivel I de excelencia, y en Clasificación Integrada de Revistas Científicas (CIRC): Grupo C; además está Catalogada en Dialnet (Universidad de La Rioja, España), y en la Red de Bibliotecas Universitarias (REBIUN) de la Conferencia de Rectores de Universidades Españolas (CRUE).

11. Los trabajos con pedido de publicación deben ser enviados al Director de los Cuadernos de Política Exterior Argentina a las siguientes direcciones de correo electrónico: cerir@unr.edu.ar ó abologna@unr.edu.ar 


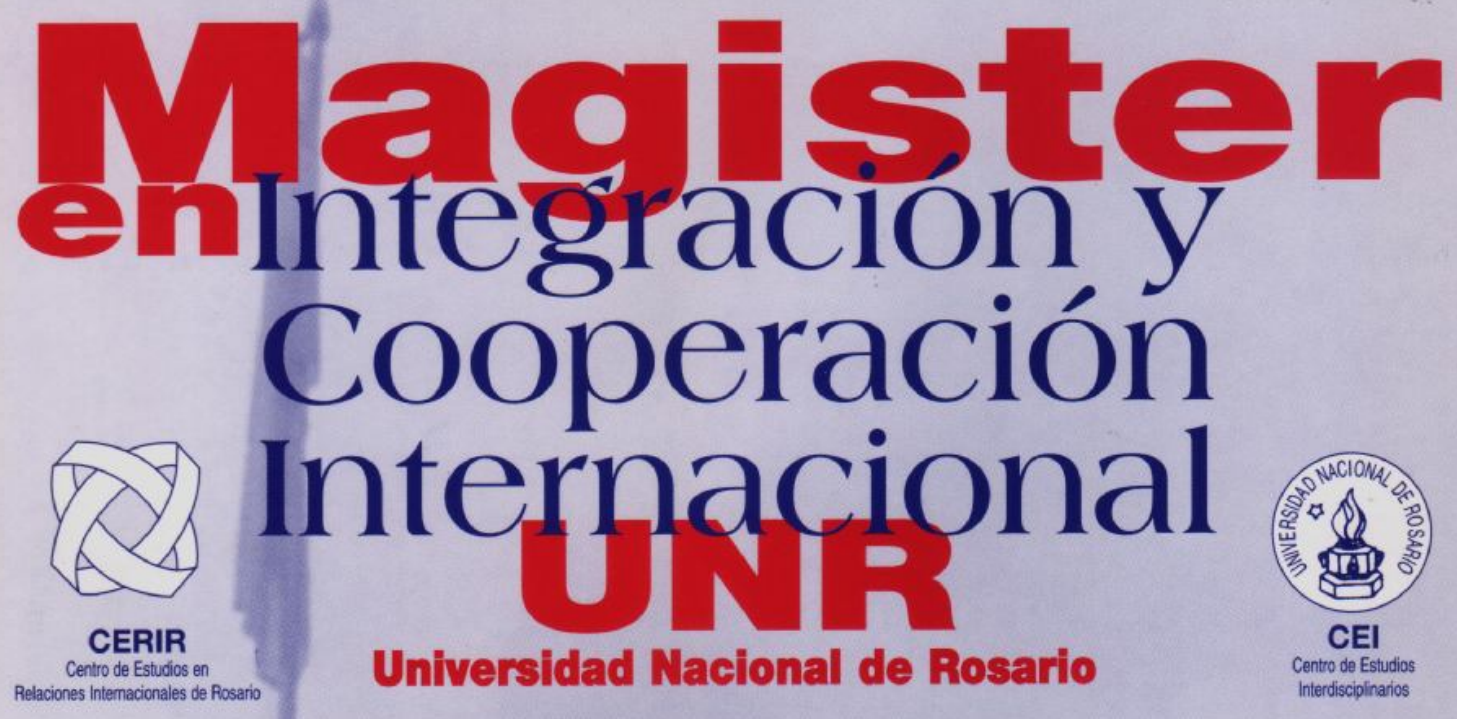

Aprobado por el Ministerio de Cultura y Educación de la Nación (Res. 902/1996) Categoría "B" - CONEAU (Res. 266/2011)

\begin{tabular}{|c|c|}
\hline $\begin{array}{r}\text { Inscripción: } \\
\text { yo a julio años pares } \\
\text { Inicio año lectivo: } \\
\text { agosto años pares } \\
\text { Duración: } \\
2 \text { años }\end{array}$ & $\begin{array}{l}\text { Informes: } \\
\text { Centro de Estudios en Relaciones } \\
\text { Internacionales de Rosario (CERIR) } \\
\text { Sede de Gobierno UNR } \\
\text { Maipú 1065, } 3^{\circ} \text { piso, of. } 301 \\
\text { Horario de atención: } \\
\text { Lunes a sábado de 9:00 a 12:00 hs. } \\
\text { Telefax: 0054 - } 341 \text { - } 4201231 \\
\text { E-mail: mici@unr.edu.ar }\end{array}$ \\
\hline
\end{tabular}

Consultar por becas parciales www.cerir.com.ar 
Impreso en:

Faxprint

San Martín 2082

Rosario (Santa Fe), junio 2015

Tirada 500 ejemplares 